\title{
8. CALCAREOUS NANNOFOSSIL QUANTITATIVE BIOSTRATIGRAPHY OF HOLES 969E AND 963B (EASTERN MEDITERRANEAN) ${ }^{1}$
}

\author{
Enrico Di Stefano ${ }^{2}$
}

\begin{abstract}
The distribution patterns of the selected biostratigraphically useful calcareous nannofossils were analyzed in the PliocenePleistocene sequences of Holes 969E and 963B drilled during Ocean Drilling Program Leg 160 (Eastern Mediterranean). Quantitative methods were used to verify the reliability of the sequence of calcareous nannofossil events detected during ODP Leg 107, Site 653 in the Western Mediterranean. In the Mediterranean record, just above the base of the Zanclean, the Reticulofenestra pseudoumbilicus paracme interval can be used to improve biostratigraphic resolution in the basal Pliocene record. At the base of the sequence of Hole 969E only the uppermost part of the Reticulofenestra pseudoumbilicus paracme was identified. It is concluded, therefore, that a short segment is not present at the local base of the Pliocene.
\end{abstract}

\section{INTRODUCTION}

A calcareous nannofossil biostratigraphic scheme for the Mediterranean Pliocene-Pleistocene record was proposed by Raffi and Rio (1979) with reference to Deep Sea Drilling Project (DSDP) Leg 13 Site 132. Rio et al. (1990) revised this scheme after detailed analysis of Leg 107 Site 653, which reoccupied Site 132. Essentially based on the sequence of extinction levels of Discoaster taxa during the Pliocene (only the MNN12/13 and MNN14-15/MNN16a zonal boundaries are defined by nonasterolith markers) and on the evolution of the Gephyrocapsa complex in the Pleistocene (Fig. 1), this zonal scheme for the Western Mediterranean has been widely accepted and used in several studies (Di Stefano and Sprovieri, 1990; Channell et al.,1992; Di Stefano et al., 1993; Castradori, 1993). The detailed analysis of calcareous nannofossils from the Pliocene-Pleistocene sequence of Hole 969E provided the opportunity to apply this zonal scheme to an Eastern Mediterranean geologic section, to compare the calcareous nannofossil evolution in these two different Mediterranean sub-basins. Hole 963B was drilled seaward of the Sicilian Capo Rossello land section (Fig. 2). The recovered sequence encompasses the stratigraphic interval between the uppermost level outcropping at Capo Rossello, referable to the first occurrence (FO) of large Gephyrocapsa (Di Stefano et al., 1993) and the Holocene. This hole is therefore important for reporting the sequence of bioevents that can be only sporadically identified, and only for the upper part of the lower Pleistocene, in outcropping sections along the southern coast of Sicily (Di Stefano et al., 1991).

\section{MATERIALS}

Holes 969E and 963B were studied. Hole 969E is located on the Mediterranean Ridge, about $100 \mathrm{~km}$ south of the island of Crete, on a ridge that separates the Ionian Basin from the Levantine Basin (Fig. 2). A total of 133 samples of the Pliocene-Pleistocene Unit I were examined from Hole 969E (from Cores 1 through 11). The pelagic sequence includes more than 80 sapropel layers. Two samples per section were studied with a maximum sample spacing of $\sim 70 \mathrm{~cm}$. Ac-

${ }^{1}$ Robertson, A.H.F., Emeis, K.-C., Richter, C., and Camerlenghi, A. (Eds.), 1998. Proc. ODP, Sci. Results, 160: College Station, TX (Ocean Drilling Program).

${ }^{2}$ Department of Geology and Geodesy-Corso, Tuköry 131-90100, Palermo, Italy. edist@mbox.unipa.it cording to the estimated sediment accumulation rate (see the following), a time interval of $\sim 35 \mathrm{k} . \mathrm{y}$. is represented per $70 \mathrm{~cm}$ of core. The underlying upper Messinian Unit II is represented by $\sim 2 \mathrm{~m}$ of calcareous silty clay that was not included in this study.

Hole 963B is located in the Strait of Sicily (Fig. 2), on the unstable foreland of North Africa, close to the deformation front of the Gela Nappe. The sediments of the single recognized sedimentary unit are nannofossil ooze, with minor intercalations of silt, volcanic ash, and clay intervals. Samples examined totalled 253. Two samples from each section were studied with a maximum sample spacing of about $70 \mathrm{~cm}$. As reported subsequently, this sample spacing covers a time interval of $\sim 9$ k.y. in lower Pleistocene sediments and $\sim 3$ k.y. in the middle Pleistocene through Holocene sediments.

\section{METHODS}

Smear slides for light microscope analyses were prepared according to standard techniques. The scanning electron microscope (SEM) was used only to investigate the Emiliania huxleyi FO according to the methodology introduced by Thierstein et al. (1977). The same unprocessed material that was used to prepare smear slides was smeared on a SEM stub. To maintain the unaltered state of the nannofossil associations, no nonbiogenic material was removed. Taxon identification was conducted by light microscopy (transmitted light and crossed nicols) at magnifications of $\sim 1000 \times$.

Abundance estimates of the nannofossils in the slides were made with the following categories:

Abundant $=$ usually more than 10 specimens occurring per field;

Common $=1-10$ specimens per field;

Few $=1$ specimen per $1-10$ fields; and

Rare $=1$ specimen per more than 10 fields

The qualitative evaluation of the state of preservation of the calcareous nannofossils was made with the following criteria:

Good $=$ specimens exhibit little or no dissolution and/or overgrowth;

Moderate to good $=$ specimens exhibit slight to moderate dissolution and/or overgrowth, and the identification of some species is impaired;

Moderate $=$ specimens exhibit moderate dissolution and/or overgrowth, and identification is impaired at the specific level; and

Poor $=$ specimens exhibit extreme dissolution and/or overgrowth. 


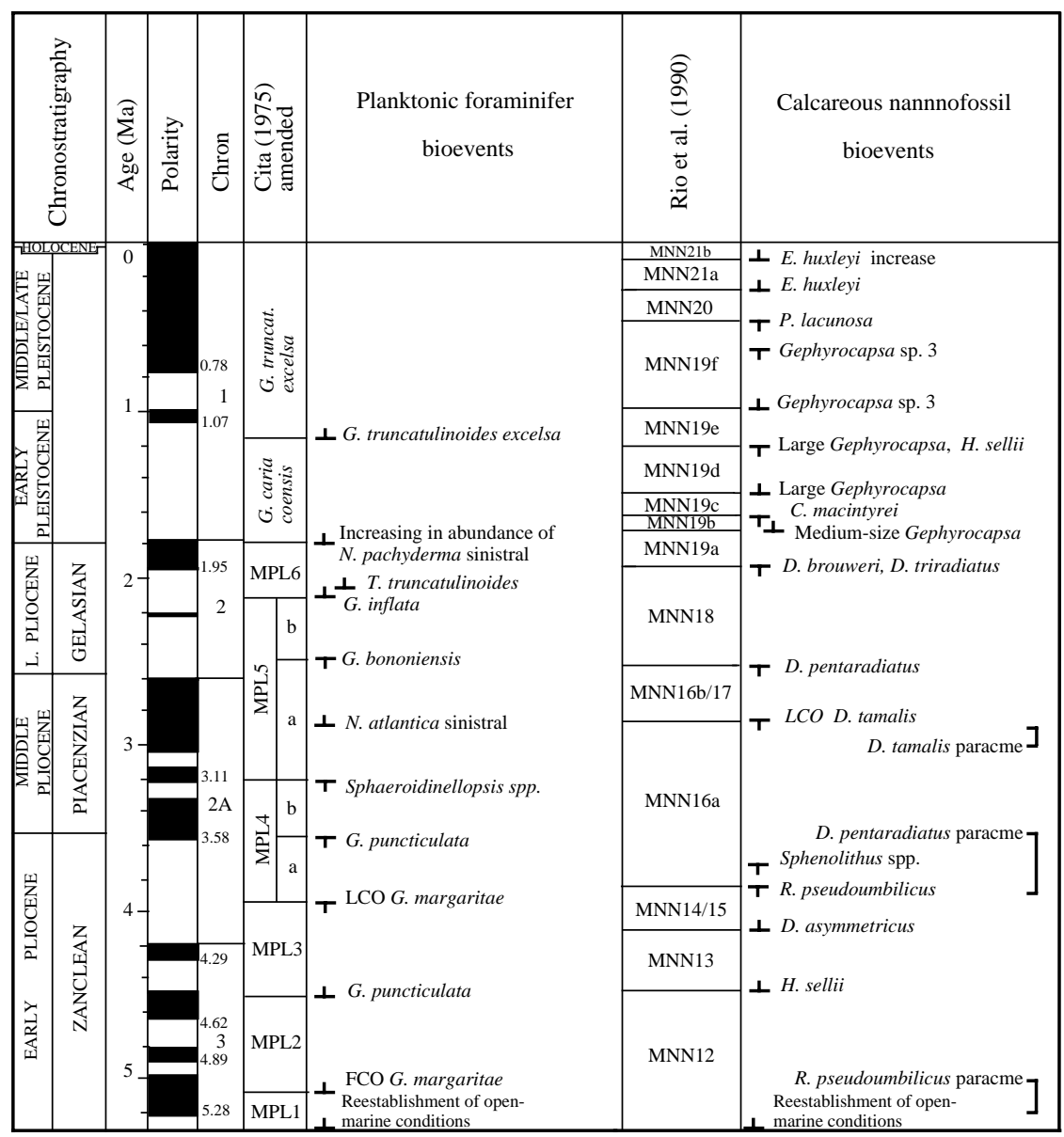

Figure 1. Adopted calcareous nannofossil biostratigraphic scheme for the Pliocene-Pleistocene Mediterranean record from Rio et al. (1990) correlated to the chronostratigraphy, geomagnetic polarity time scale, and planktonic foraminifer bioevents. In the right-hand column, the positions of second-order events are also reported.

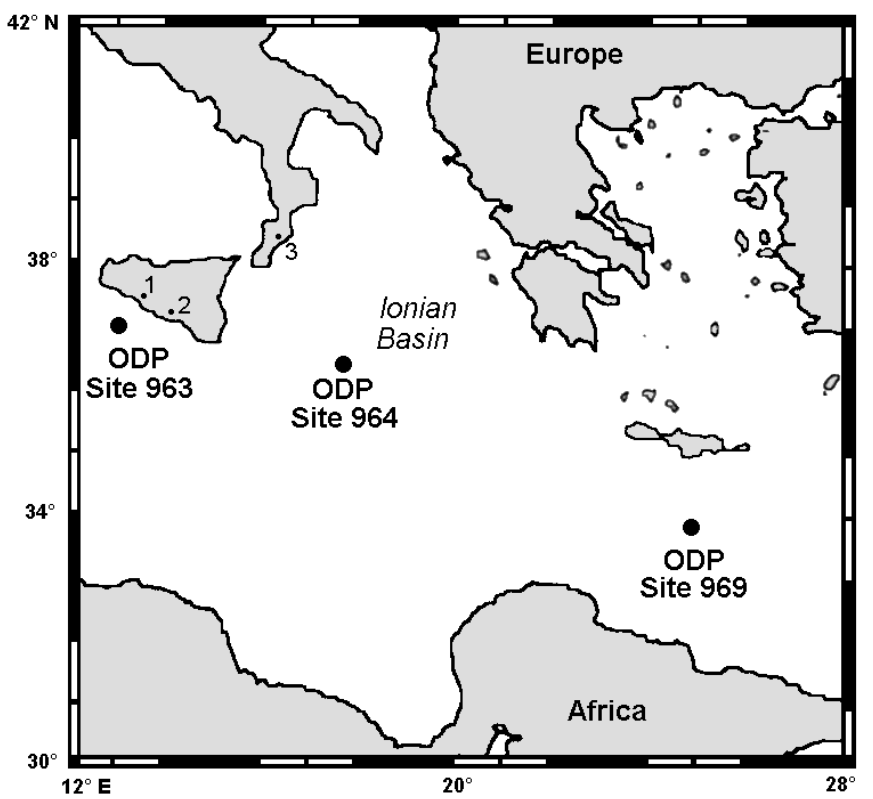

Figure 2. Index map with the location of ODP Sites 969, 964, and 963. $1=$ Capo Rossello-Punta Piccola; 2 = Monte San Nicola; 3 = Capo SpartiventoRoccella Jonica.
Abundance data of nannofossil taxa were collected by quantitative methods. Their application in calcareous nannofossil biostratigraphy and biochronology studies has been discussed at length by Backman and Shackleton (1983) and Rio et al. (1990).

The following counting methods were applied in this work:

1. Index species vs. the total assemblage was used to detect the $E$. huxleyi FO and its increase and the Pseudoemiliania lacunosa last occurrence (LO). Counts were restricted to the first 300 nannofossils for $E$. huxleyi and to the first 500 for P. lacunosa.

2. Index species vs. a fixed number of taxonomically related forms. This method was used to detect the abundance patterns of Discoaster markers relative to 100 asteroliths, Calcidiscus macintyrei relative to 100 Calcidiscus, Helicosphaera sellii relative to 50 helicoliths, medium-sized Gephyrocapsa relative to 300 placoliths $>3 \mu \mathrm{m}$, large Gephyrocapsa relative to 100 Gephyrocapsa spp. $>4 \mu \mathrm{m}$, and Gephyrocapsa sp. 3 relative to 100 Gephyrocapsa spp. $>4 \mu \mathrm{m}$.

3 . The number of specimens of a taxon in a pre-determined area of the slide $\left(4.52 \mathrm{~mm}^{2}\right)$ was utilized to quantify:

a. The total accumulation of the genus Discoaster through the record;

b. The early Pliocene bioevents relative to P. lacunosa and the Amaurolithus and Ceratolithus index forms; and

c. The relative abundance of Reticulofenestra pseudoumbilicus and Sphenolithus spp. (Sphenolithus abies and S. neoabies). 


\section{TAXONOMY}

The taxonomic concepts of Backman and Shackleton (1983), Rio et al. (1990), and Raffi et al. (1993) were followed. They have been adopted by previous authors who studied the Pliocene-Pleistocene Mediterranean record (Channell et al.,1992; Castradori, 1993; Di Stefano et al., 1993; Glaçon et al., 1990).

\section{BIOSTRATIGRAPHY}

The Mediterranean region acted as a distinct biogeographic province during the Pliocene-Pleistocene time interval (Thunell, 1979; Berggren, 1984). As a consequence, regional calcareous plankton biostratigraphic schemes have been proposed by different authors (Cita, 1975; Colalongo and Sartoni, 1979; Spaak, 1983; Iaccarino, 1985; and Sprovieri, 1992 for planktonic foraminifers; and Bukry, 1973; Schmidt, 1973; Müller, 1978; Ellis, 1979; Raffi and Rio, 1979; and Rio et al., 1990 for calcareous nannofossils).

Previous studies on the Pliocene-Pleistocene calcareous nannofossil biostratigraphy of the Mediterranean were summarized by Rio et al. (1990). They introduced quantitative definitions for the zonal boundaries. Their scheme, correlated with the standard zonations of Martini (1971) and Okada and Bukry (1980), was adopted in subsequent studies of land sections in the Western Mediterranean (Channell et al., 1992; Di Stefano et al., 1993) and in Quaternary deep-sea cores recovered in the Eastern Mediterranean (Castradori, 1993). This scheme is adopted here, but as modified by Sprovieri et al. (1994). Sprovieri et al. (1994) define the upper boundary of the Zone MNN16a by the last common occurrence (LCO) of Discoaster tamalis and not by the LO of the marker species (Fig. 2). The LCO coincides with the uppermost sharp decrease of $D$. tamalis above the paracme interval.

\section{CHRONOSTRATIGRAPHY}

\section{Miocene/Pliocene Boundary}

The Global Stratotype Section and Point (GSSP) of this boundary was recently proposed by Hilgen and Langereis (1993) at the base of the Trubi sequence in the Eraclea Minoa section (Southern Sicily) since at Capo Rossello, where Cita (1975) proposed this boundary, paleomagnetic data could not be obtained. The proposal by Benson and Rakic-El Bied (1996), to define this boundary in the Bou Regreg section (Morocco), in coincidence of the base of the $\mathrm{C} 3 \mathrm{r}$ paleomagnetic interval, is controversial and still under discussion.

Following Hilgen and Langereis (1993) the recognition of this boundary in the open-ocean record is difficult, owing to a lack of biostratigraphic markers at this stratigraphic level. Recent papers based on land sections that crop out in Calabria show that this boundary occurs slightly (five precession astronomical cycles) below the base of the Thvera subchron and slightly below the Triquetrorhabdulus rugosus LO (Channell et al., 1988; Hilgen and Langereis, 1988; Di Stefano et al., 1996). Therefore, this boundary has an age of about 5.33 Ma (Hilgen, 1991b; Sprovieri, 1993). In extra-Mediterranean marine sequence this boundary is within Subzone CN10a of the Okada and Bukry (1980) zonation scheme.

\section{Pliocene}

The Pliocene two-fold chronostratigraphic scheme of Berggren et al. (1985) was discussed by Rio et al. $(1991,1994)$ and Cita et al. (in press), who propose a three-fold subdivision based on well-established stratotype boundaries. Consequently, the Pliocene Series is subdivided into the Zanclean, Piacenzian, and Gelasian Stages. The base of the Zanclean is defined at the base of the Trubi sequence, which crops out at Capo Rossello (Cita and Gartner, 1973). This boundary is at the same lithological level as the Miocene/Pliocene boundary proposed by Cita (1975). The Zanclean chronostratigraphic unit spans the interval between the base of the Pliocene and the base of the Piacenzian. After the revision of the Piacenzian stratotype section (Rio et al., 1988), the GSSP of the base of the Piacenzian is proposed by Cita et al. (1996) coinciding with lithologic small-scale cycle 77 of Hilgen (1991a). In this cycle, which crops out at the base of the Punta Piccola section (Agrigento, Southern Sicily), the Gilbert/ Gauss boundary was identified at the top, and the LO of Globorotalia puncticulata was recognized in lithologic cycle 79 (Hilgen, 1991a).

The GSSP of the base of the Gelasian Stage (recently ratified by International Union Geological Sciences (IUGS) is defined in the Monte San Nicola section (Gela, Southern Sicily) (Rio et al., 1994), coinciding with a laminated level correlated to the oxygen isotopic Stage 103. No bioevents are present at the base of this stage. The best approximation for its recognition is the LO of Discoaster pentaradiatus, which in the stratotype section is $\sim 0.089$ Ma younger than the boundary stratotype.

\section{Pliocene/Pleistocene Boundary}

This boundary, ratified by IUGS in the Vrica (stratotype boundary) section (Calabria, Italy; Aguirre and Pasini, 1985; Bassett, 1985), is best approximated by the first increase of the planktonic foraminifer left-coiling Neogloboquadrina pachyderma and the FO of the calcareous nannofossil Gephyrocapsa oceanica s.l. (= FO of medium-size Gephyrocapsa spp., according to Raffi et al. 1993).

In this study the Pleistocene is divided into the lower and middleupper Pleistocene. The definition of this boundary is still under discussion (Cita and Castradori, 1995). One of the proposed options is the recognition of this boundary by the FO of Gephyrocapsa sp. 3 . This option was followed during shipboard studies of Leg 160 (Emeis, Robertson, Richter, et al., 1996) and in this paper.

\section{RESULTS}

\section{Hole 969E}

Calcareous nannofossils are abundant in all samples from Unit I. The assemblages are rich, well diversified, and show good to moderate-good preservation. Etching is minimal and present only in some sapropel layers. A moderate degree of overgrowth is observed mainly in the lower Pliocene interval. Reworking is minimal. The relative distribution patterns of the species are comparable to that reported by Rio et al. (1990) for the Western Mediterranean. The stratigraphic position of the recognized events is listed in Table 1. The biostratigraphic and chronostratigraphic subdivision of the sequence is summarized in Figure 3. The distribution patterns of the considered taxa are plotted in Figures 4-11.

In Unit II, the calcareous nannofossil assemblages are few to common and specimens exhibit moderate to moderate-good preservation conditions. Reworked taxa (Micula decussata, Cribrosphaerella ehrembergii, Cyclicargolithus floridanus, and Dictyococcites bisectus) from older sediments are present with nondiagnostic taxa that range from the Miocene to Pliocene. They include Sphenolithus abies, Coccolithus pelagicus, Discoaster pentaradiatus, Calcidiscus macintyrei, and Reticulofenestra spp. and are interpreted as reworked from upper Miocene sediments of late Messinian. The transition between Unit I and Unit II is sharp, as evidenced by a strong change in the abundance and composition of the assemblages. This change is considered indicative of the re-establishment of open-marine conditions above the upper Messinian Unit II at the base of the Pliocene (Cita, 1975; Rio et al., 1984). In this hole, the base of the Pliocene is not represented, as evidenced by a hiatus whose duration has been estimated at 200 k.y. (see below). 
Table 1. Summary of the stratigraphic positions of calcareous nannofossil events at Hole 969E.

\begin{tabular}{|c|c|c|c|}
\hline Event & $\begin{array}{l}\text { Core, section, } \\
\text { interval }(\mathrm{cm})\end{array}$ & $\begin{array}{l}\text { Depth } \\
\text { (mbsf) }\end{array}$ & $\begin{array}{l}\text { Error limit } \\
\quad(\mathrm{cm})\end{array}$ \\
\hline & $160-969 \mathrm{E}-$ & & \\
\hline E. huxleyi increase & $1 \mathrm{H}-2,39-40$ & 1.89 & 87 \\
\hline E. huxleyi $\mathrm{FO}$ & $2 \mathrm{H}-1,118-119$ & 6.08 & 66 \\
\hline P. lacunosa LO & $2 \mathrm{H}-5,104-105$ & 11.94 & 65 \\
\hline Gephyrocapsa sp.3 LO & $2 \mathrm{H}-7,39-40$ & 14.29 & 70 \\
\hline Gephyrocapsa sp.3 FO & $3 \mathrm{H}-2,117-118$ & 17.07 & 72 \\
\hline Large Gephyrocapsa LO & $3 \mathrm{H}-5,113-114$ & 21.53 & 74 \\
\hline H. sellii LO & $3 \mathrm{H}-5,113-114$ & 21.53 & 74 \\
\hline Large Gephyrocapsa FO & $4 \mathrm{H}-1,123-124$ & 25.13 & 66 \\
\hline C. macintyrei $\mathrm{LO}$ & $4 \mathrm{H}-3,123-124$ & 28.13 & 84 \\
\hline Medium-size Gephyrocapsa FO & $4 \mathrm{H}-4,39-40$ & 28.79 & 84 \\
\hline D. brouweri LO & $4 \mathrm{H}-7,38-39$ & 33.28 & 65 \\
\hline D. triradiatus LO & $4 \mathrm{H}-7,38-39$ & 33.28 & 65 \\
\hline D. triradiatus increase & $5 \mathrm{H}-2,39-40$ & 35.29 & 71 \\
\hline D. pentaradiatus $\mathrm{LO}$ & $5 \mathrm{H}-\mathrm{CC}$ & 42.93 & 14 \\
\hline D. syracuse LO & $5 \mathrm{H}-\mathrm{CC}$ & 42.93 & 14 \\
\hline D. tamalis LCO & $6 \mathrm{H}-4,109-110$ & 48.49 & 70 \\
\hline D. pentaradiatus paracme top & $8 \mathrm{H}-2,39-40$ & 63.79 & 80 \\
\hline Sphenolithus spp. LO & $8 \mathrm{H}-3,109-110$ & 65.99 & 70 \\
\hline R. pseudoumbilicus LO & $8 \mathrm{H}-5,109-110$ & 68.99 & 70 \\
\hline D. pentaradiatus paracme bottom & $8 \mathrm{H}-6,39-40$ & 69.79 & 70 \\
\hline A. delicatus $\mathrm{LO}$ & $9 \mathrm{H}-1,40-41$ & 71.8 & 131 \\
\hline P. lacunosa FO & $9 \mathrm{H}-1,40-41$ & 71.8 & 69 \\
\hline D. tamalis FO & $9 \mathrm{H}-1,109-110$ & 72.49 & 81 \\
\hline D. asymmetricus $\mathrm{FCO}$ & $9 \mathrm{H}-4,109-110$ & 76.99 & 81 \\
\hline A. primes $\mathrm{LO}$ & $10 \mathrm{H}-1,110-112$ & 82 & 71 \\
\hline H. sellii $\mathrm{FO}$ & $10 \mathrm{H}-2,110-112$ & 83.5 & 79 \\
\hline C. rugosus FO & $10 \mathrm{H}-3,39-40$ & 84.29 & 71 \\
\hline A. tricorniculatus LO & $10 \mathrm{H}-3,110-112$ & 85 & 71 \\
\hline R. pseudoumbilicus paracme top & $11 \mathrm{H}-5,109-110$ & 95.49 & 67 \\
\hline
\end{tabular}

Note: $\mathrm{FO}=$ first occurrence, $\mathrm{LO}=$ last occurrence, $\mathrm{LCO}=$ last common occurrence, $\mathrm{FCO}=$ first common occurrence.

\section{Hole 963B}

Calcareous nannofossils are abundant in all analyzed samples. The assemblages are dominated by placoliths identified as Gephyrocapsa spp. These assemblages compare well to the Quaternary assemblages reported for the Mediterranean Basin by Müller (1978, 1990). Reworked Pliocene, Miocene, Eocene, and Late Cretaceous species also occur. The abundance of reworked taxa increases upsection, beginning at about $115 \mathrm{~m}$ below sea floor (mbsf), which indicates that during this time interval the sources for reworking were more active. Evidence of similar reworking was documented from lower Pleistocene land sections that outcrop along the southern coast of Sicily (Channell et al., 1992, Di Stefano et al., 1993).

Preservation of the in situ Pleistocene assemblages is generally good. Nevertheless, because of strong reworking the recognition of the LO of $P$. lacunosa can be identified with accuracy only by quantitative analyses. The biostratigraphic and chronostratigraphic subdivision of the sequence studied from Hole 963B is reported in Figure 12. The stratigraphic positions of the recognized events are listed in Table 2. The distribution patterns of the considered taxa are plotted in Figure 13.

\section{BIOSTRATIGRAPHIC REMARKS}

The same sequence of biozones reported from the Tyrrhenian Sea study of Rio et al. (1990) was identified in the Holes 969E and 963B. Although the sample spacing was less than that used by Rio et al. (1990), the abundance patterns from the Eastern Mediterranean and the Tyrrhenian Basin are the same. The same stratigraphic and paleoecologic evolution, therefore, affected the calcareous nannofossil assemblages in the two Mediterranean sub-basins during the PliocenePleistocene. Several papers on calcareous nannofossil biostratigraphy pointed out the opportunity for quantitative analyses to detect the

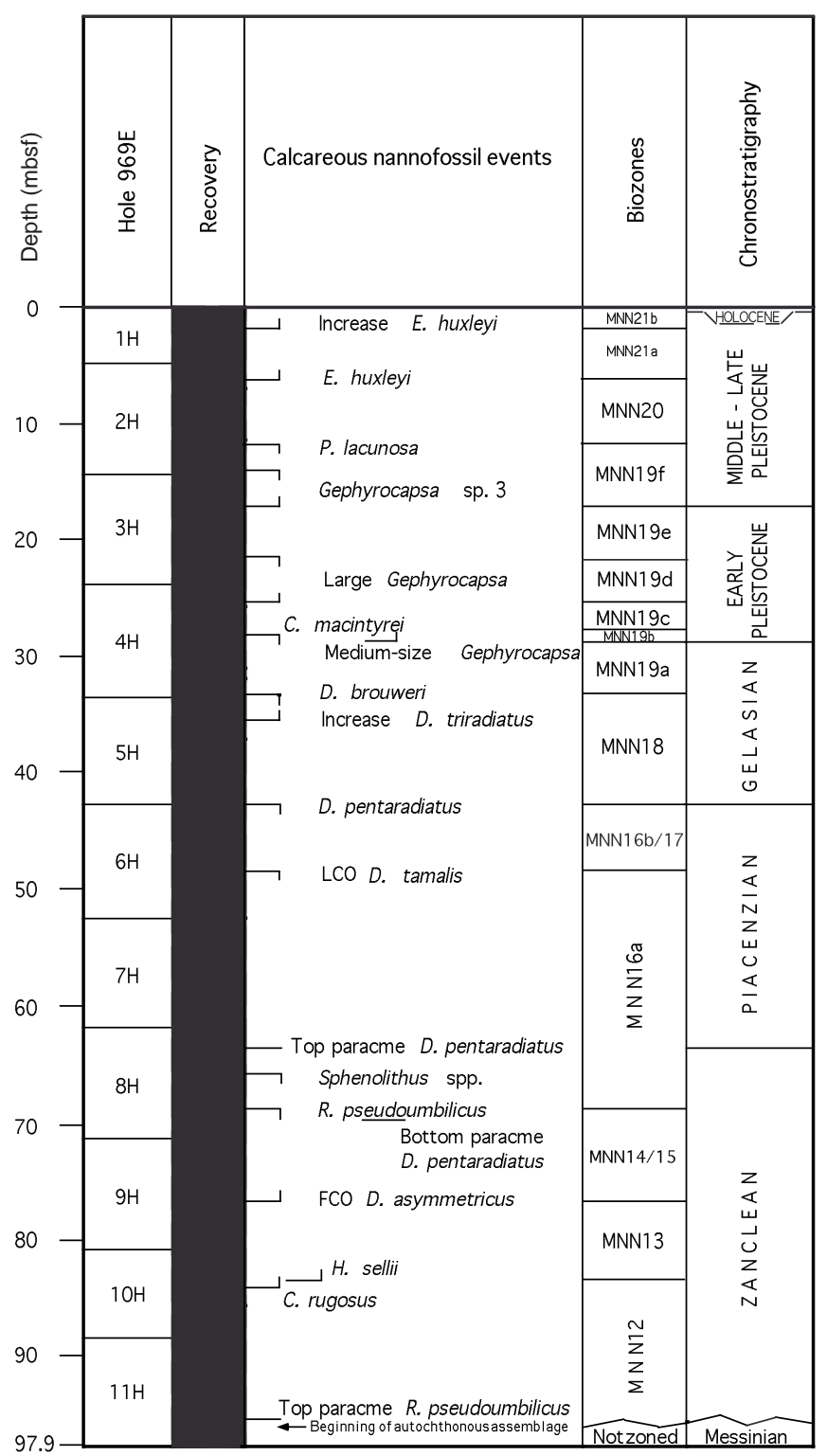

Figure 3. Composite of calcareous nannofossil biostratigraphic events recognized at Hole 969E.

biostratigraphic boundaries with accuracy. In particular, Rio et al. (1990) proposed quantitative thresholds for many of these bioevents, below or above which the species is considered biostratigraphically not relevant. Effectively, this is an essentially biostratigraphic criterion. It is not necessarily coincident with the total range of the living species. The species may occur beyond the stratigraphic level in which the proposed threshold is identified, but with very low percent values. Such low values are biostratigraphically inconsistent for the recognition of correlatable biostratigraphic boundary, particularly in the presence of strong reworking.

In addition to the identification of the primary biostratigraphic events, quantitative methods in this study resulted in the identification of some sharp changes in the relative abundance distribution during the total range of some species. As already reported implicitly by Rio et al. (1990), their importance for improving the biostratigraphic resolution based on the calcareous nannofossil assemblage is stressed 


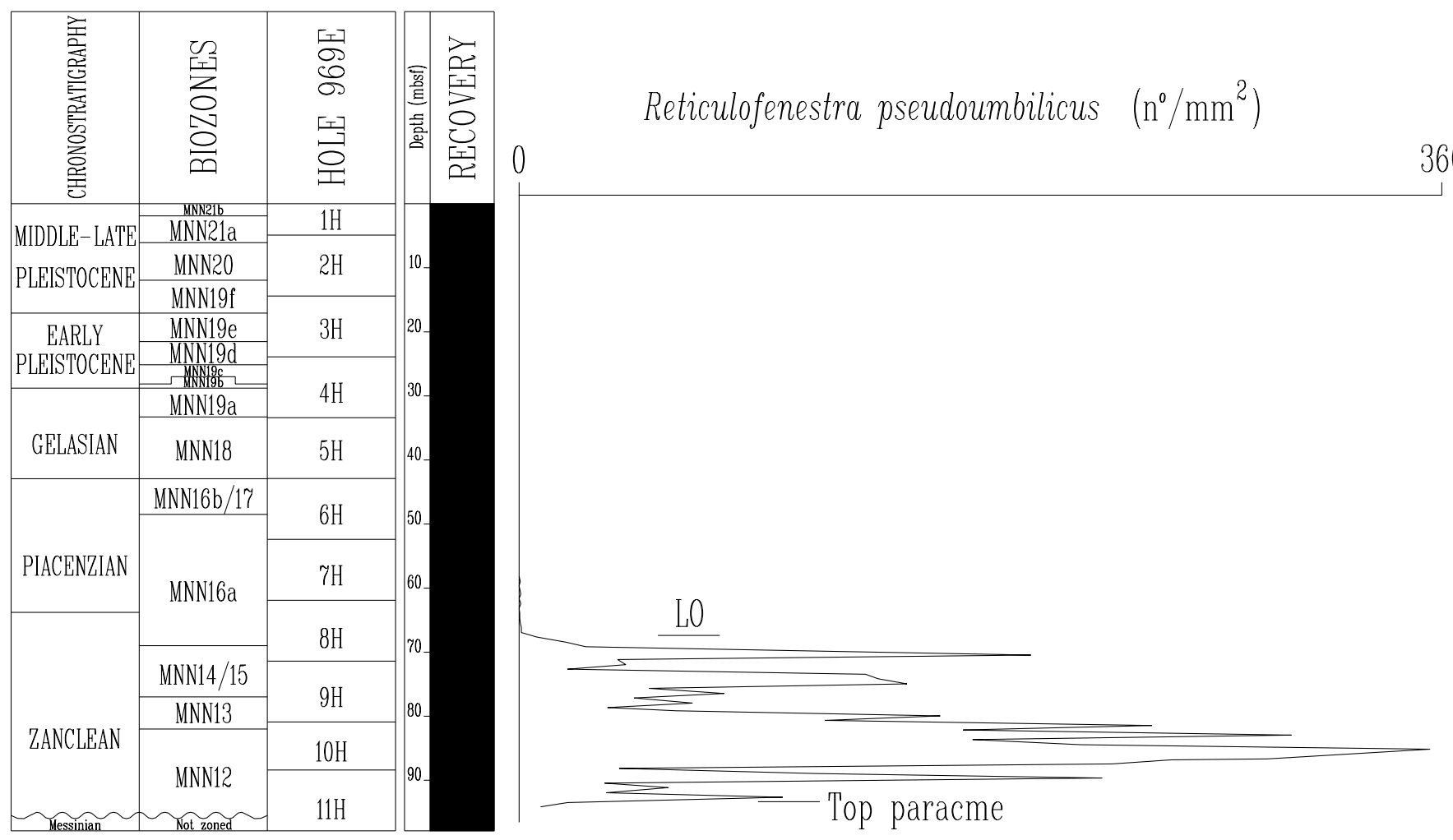

Figure 4. Abundance pattern of Reticulofenestra pseudoumbilicus in Hole 969E.

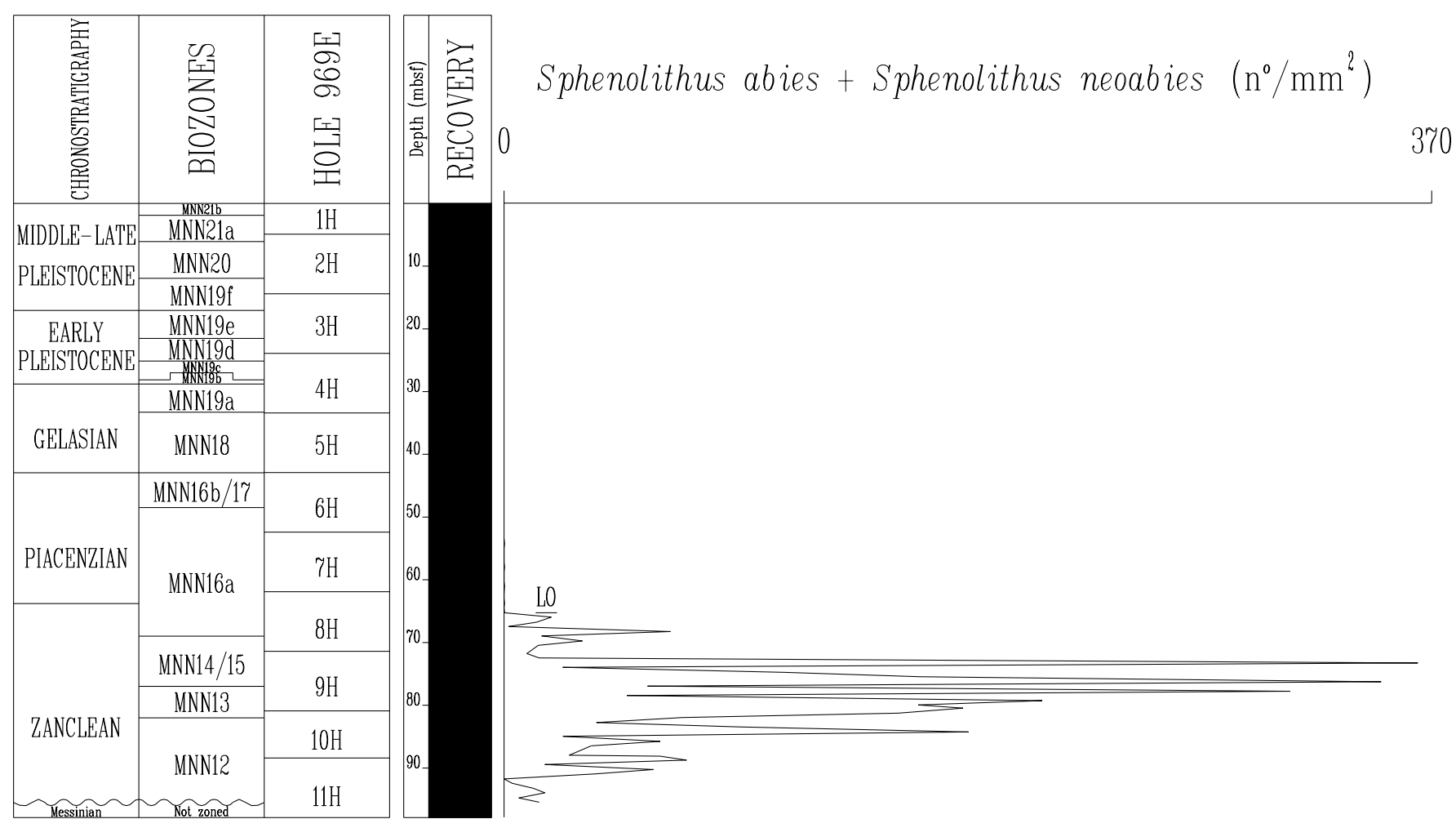

Figure 5. Abundance pattern of Sphenolithus spp. (S. abies and S. neoabies) in Hole 969E. 

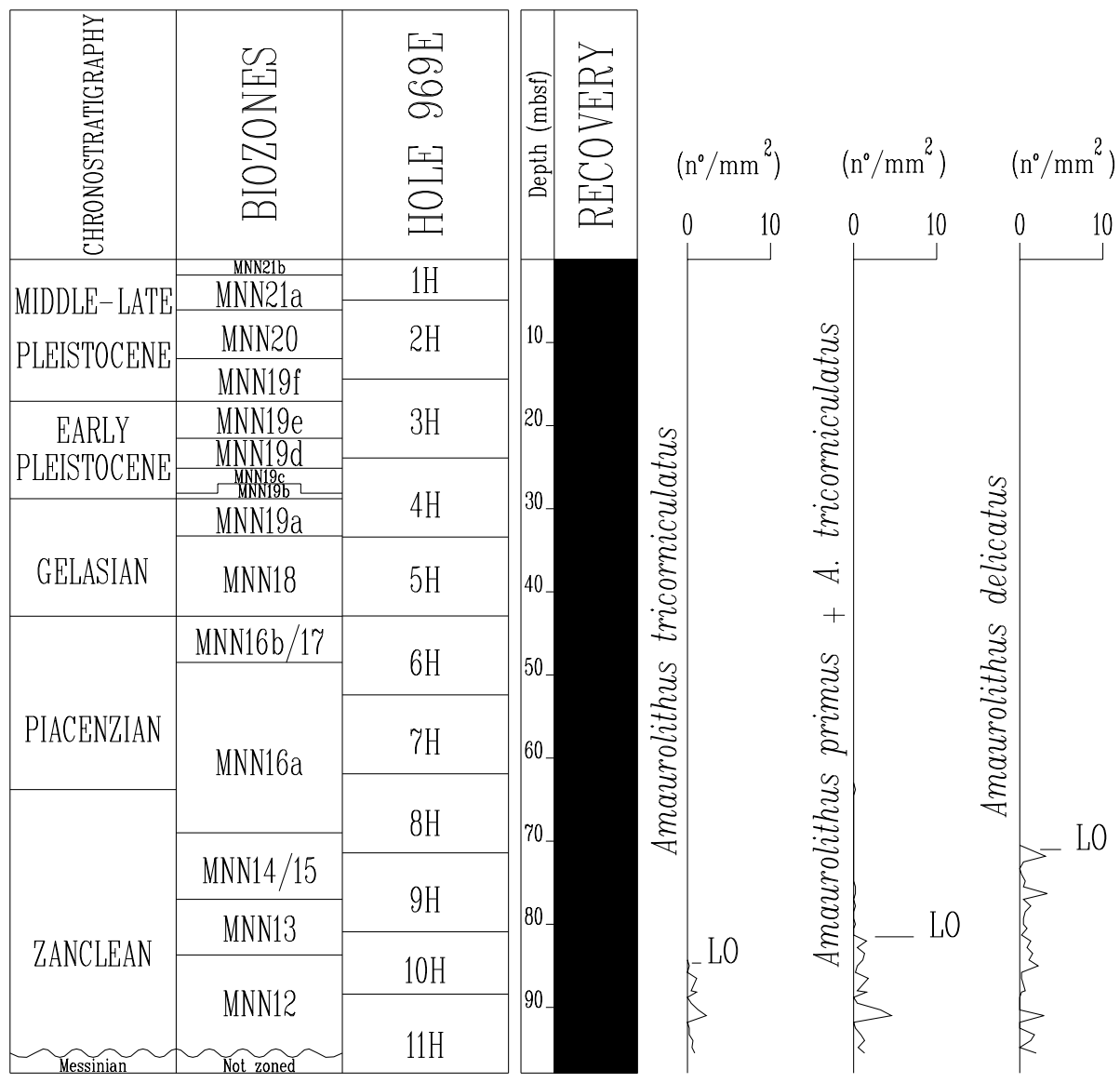

$$
\left(\mathrm{n}^{0} / \mathrm{mm}^{2}\right)
$$
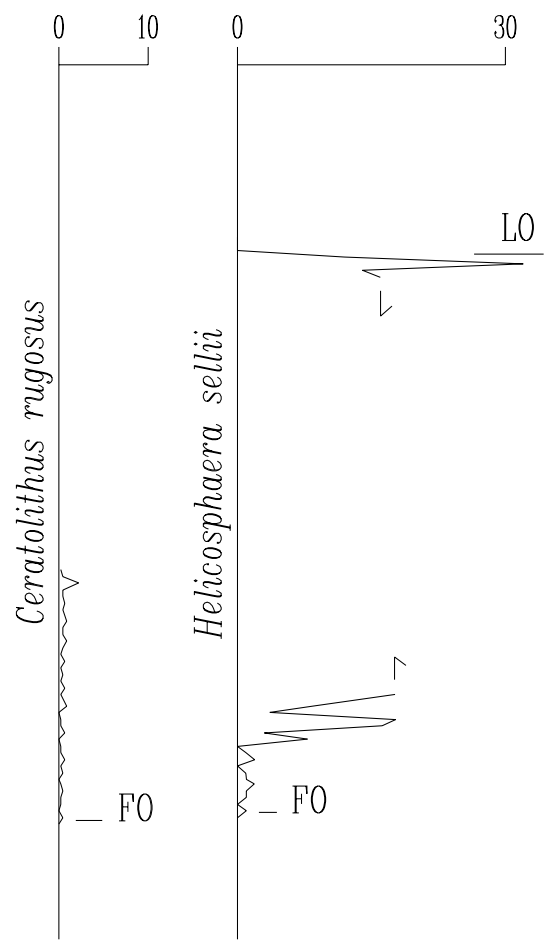

Figure 6. Abundance pattern of the ceratolith taxa in the lower Pliocene and Helicosphaera sellii in Hole 969E.

here, because evidence exists that these abundance changes may be synchronous in the Eastern and Western Mediterranean (Sprovieri et al., Chap. 12, this volume).

\section{Reticulofenestra pseudoumbilicus Paracme}

Just above the base of the Pliocene a short time interval is present during which $R$. pseudoumbilicus is absent or extremely rare compared with the underlying and overlying segments (see fig. 5 of Rio et al., 1990). Identified as the R. pseudoumbilicus paracme, it encompasses a stratigraphic interval that includes small-scale cycles 6 to 14 of Hilgen (1991b) in the Roccella Jonica-Capo Spartivento section (Di Stefano et al., 1996). The ages reported by these authors for the base and top of this paracme are 5.20 and 5.01 Ma, respectively. At Hole $969 \mathrm{E}$ the basal sediment of Unit I includes a floral assemblage in which $R$. pseudoumbilicus is very rare (94.82 mbsf). Above this level $R$. pseudoumbilicus abruptly increases in abundance (93.99 mbsf). This distribution pattern suggests that these basal levels can be correlated with the topmost part of the R. pseudoumbilicus paracme interval. Consequently, the very base of the Pliocene correlatable with the first 10-11 lithologic cycles in the Roccella Jonica-Capo Spartivento composite section, which spans $\sim 0.2 \mathrm{~m}$.y. (Di Stefano et al., 1996), is not present at the base of Hole 969E.

\section{Bioevents at the Base of MNN14/15 Zone}

At the base of MNN14/15 Zone three second order bioevents occur, respectively $D$. tamalis FO, Amaurolithus delicatus LO, and $P$. lacunosa FO. They follow each other in the Western Mediterranean sequence of Site 653 (Rio et al., 1990) and can be used to implement stratigraphic resolution within this biozone. At Hole 969E, as at Site 653 , the first clearly recognizable placoliths of $P$. lacunosa occur with abundance value below $2 \%$ in the same sample in which the $A$. delicatus $\mathrm{LO}$ was detected. These two taxa co-occur in a very short interval below the threshold (2\%) used by Rio et al.(1990) to identify the FO of P. lacunosa. Since the same trend in the distribution of these two species was recognized also in the Eastern Mediterranean Pliocene, at Hole 969E the FO of P. lacunosa is reported just in coincidence of the A. delicatus LO.

In addition at Hole 969E, small Gephyrocapsa (detected on the basis of semiquantitative observations) become common from just above the base of this biozone, and well below the P. lacunosa FO. Only rare and scattered specimens of small Gephyrocapsa are present through the underlying MNN13 Zone. These data compare well with data reported from the Western and Eastern Mediterranean by Müller (1978) and Driever (1988).

\section{Discoaster pentaradiatus Paracme}

The $D$. pentaradiatus paracme was originally identified by Driever (1981). It straddles the MNN14-15/16a boundary. The age of the base of this paracme interval, characterized by a temporary absence of the species in the Mediterranean, is $~ 3.90 \mathrm{Ma}$ (Sprovieri, 1993). The top of the $D$. pentaradiatus paracme is just above the last occurrence of Globorotalia puncticulata (Sprovieri et al., 1994; Channell et al., 1992) and the age proposed for this event is $3.56 \mathrm{Ma}$ (Sprovieri, 1993). The identification of the top of the $D$. pentaradiatus paracme allows the recognition of the lower part of the MNN16a Zone, above the extinction level of Sphenolithus spp. (Fig. 2). According to the proposal of Cita et al. (1996), the top of the D. pentaradiatus paracme 


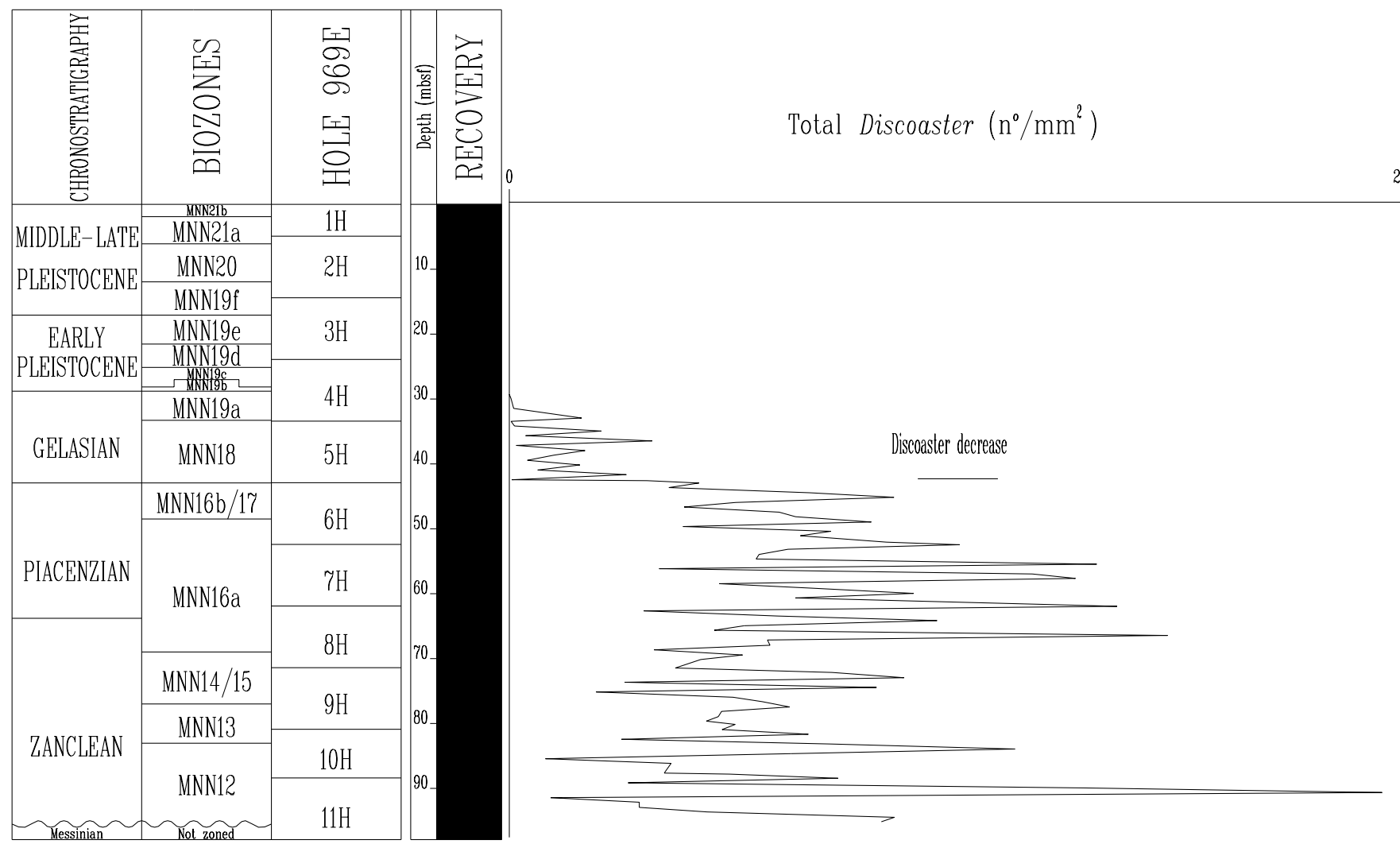

Figure 7. Discoaster abundance fluctuations in the Pliocene interval in Hole 969E.

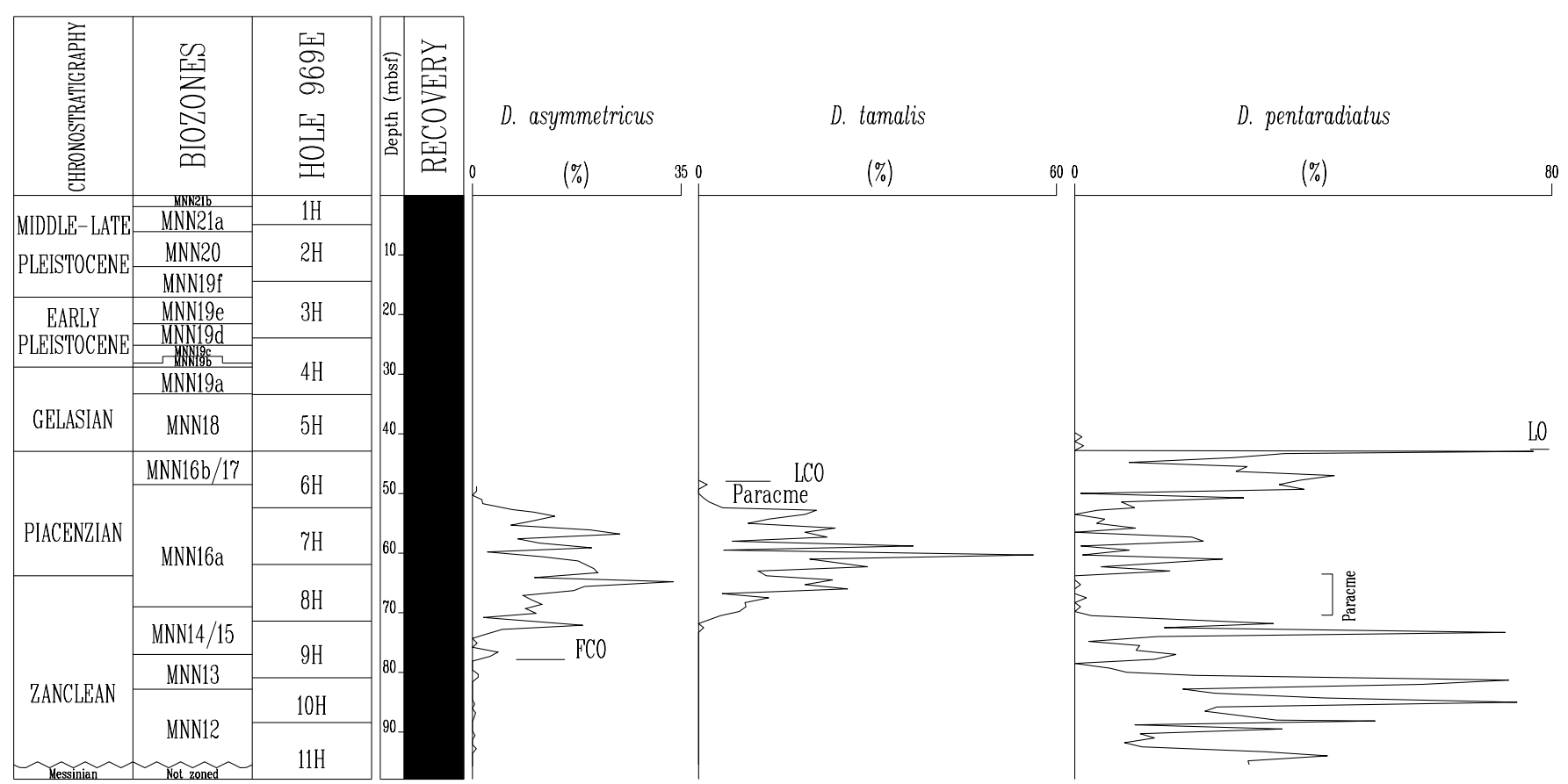

Figure 8. Abundance pattern of discoasterids relative to 100 specimens of Discoaster spp. in Hole 969E. 


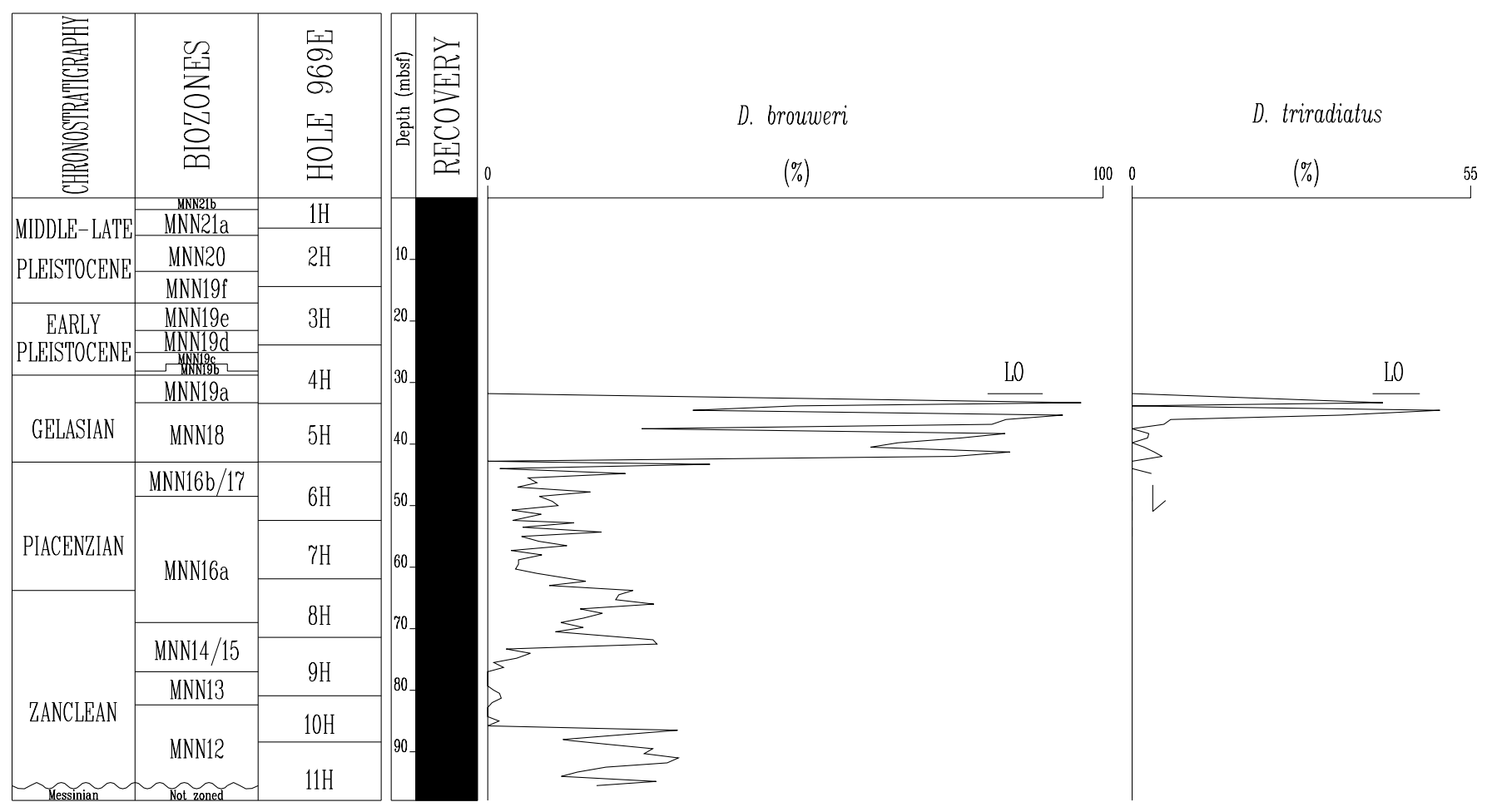

Figure 9. Abundance pattern of Discoaster brouweri relative to 100 specimens of Discoaster spp. Percentages of D. triradiatus are plotted vs. the total number of D. brouweri in Hole 969E.

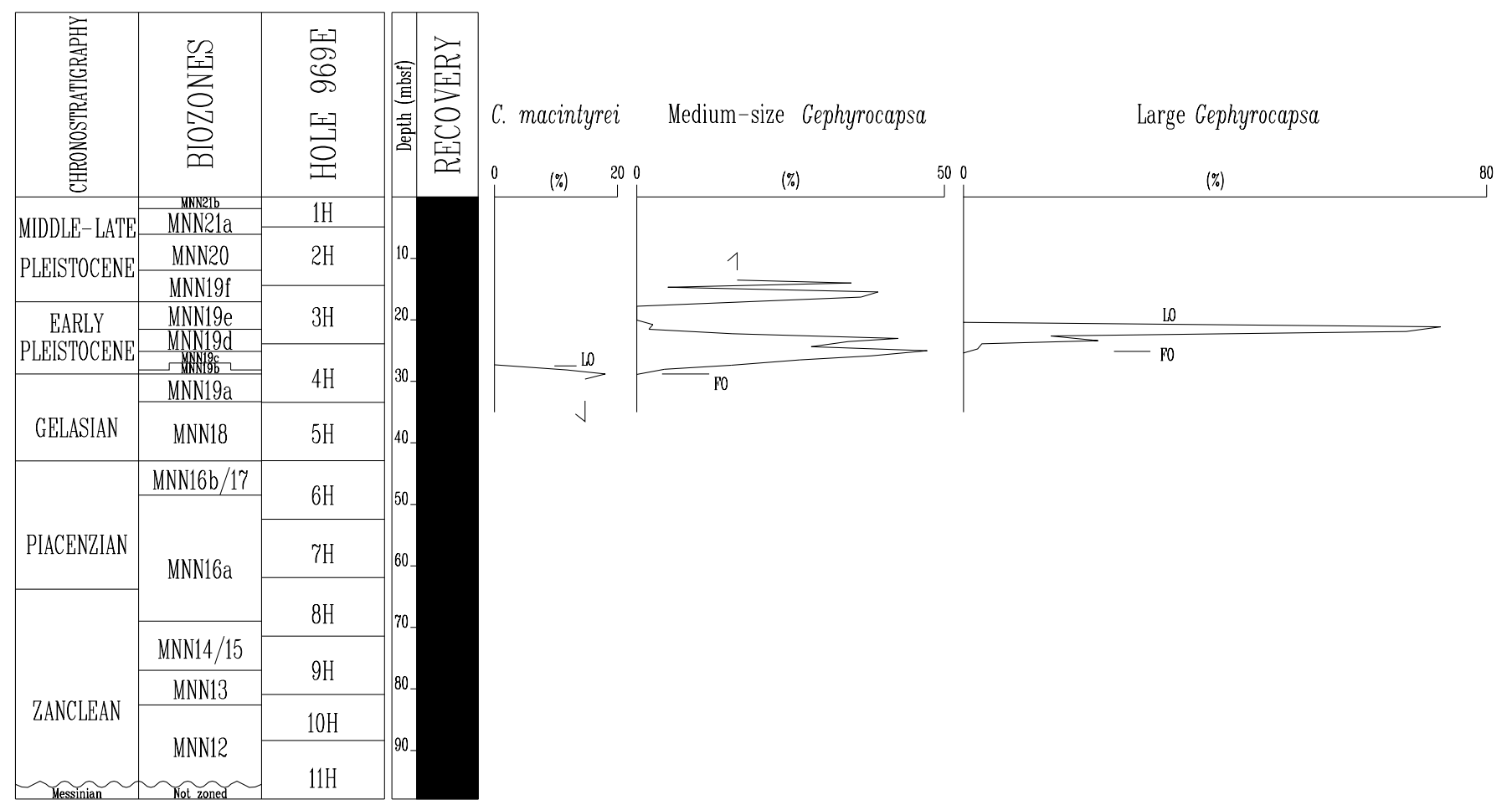

Figure 10. Abundance pattern of the Pleistocene index calcareous nannofossils in Hole 969E. 


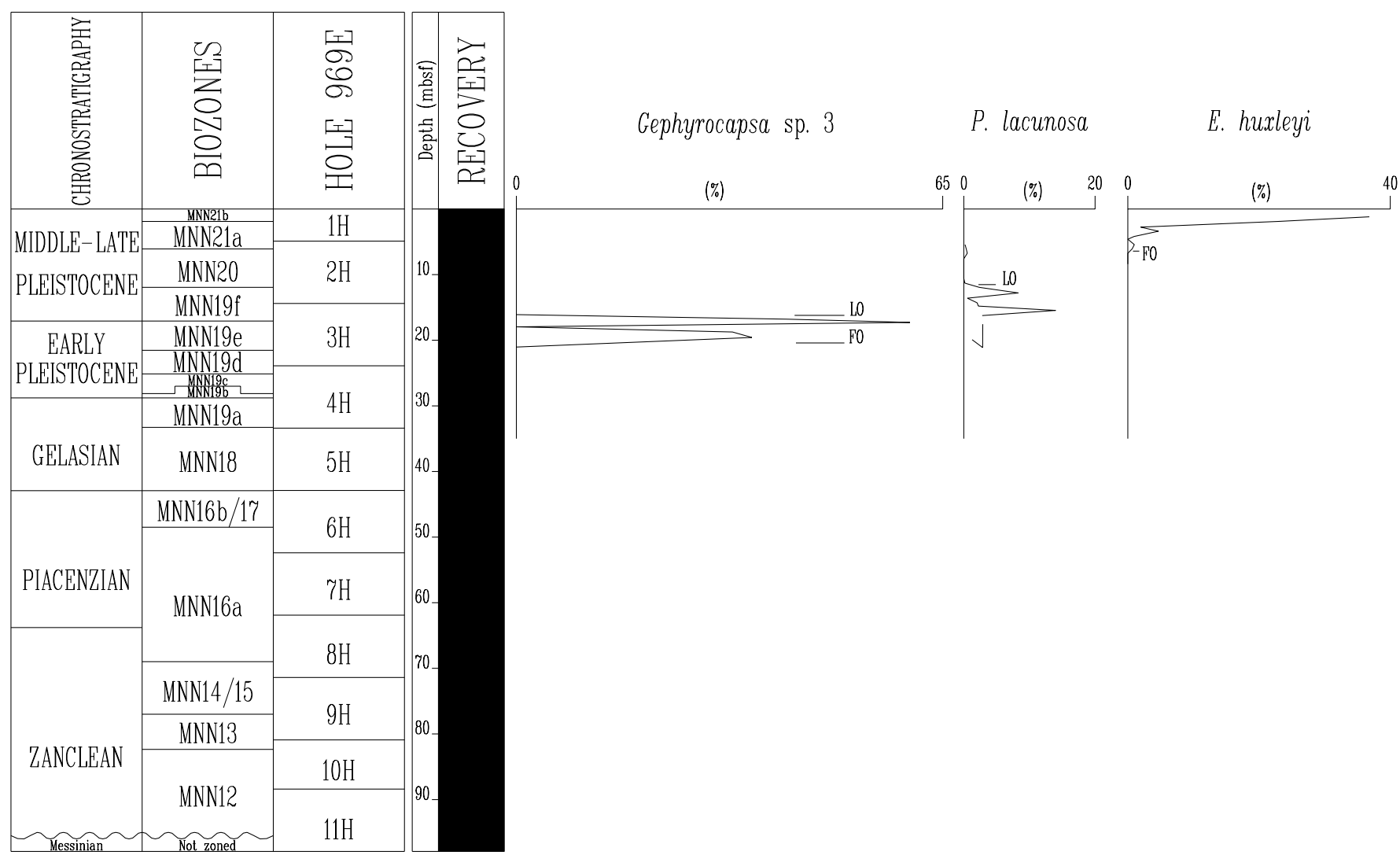

Figure 11. Abundance pattern of the middle-late Pleistocene index forms in Hole 969E.

can be used to approximate in the Mediterranean the base of the Piacenzian Stage. This option has been adopted in this paper.

\section{Discoaster asymmetricus-Discoaster tamalis Abundance Change}

In the upper part of the D. pentaradiatus paracme, close to the LO of Sphenolithus spp., a significant inversion in the quantitative distribution of $D$. asymmetricus and $D$. tamalis occurs. Below this level $D$. asymmetricus is always quantitatively prominent relative to $D$. tamalis. Above this level, up to the top of the biozone, D. tamalis is more abundant.

\section{Discoaster tamalis Paracme}

In the uppermost part of the MNN16a (Discoaster tamalis) Zone, D. tamalis displays a peculiar abundance pattern, which can be identified only with the study of closely spaced samples. Above a long interval, in which the species is always more or less frequent, it abruptly decreases in abundance and is very rare or missing. This short interval is proposed as the $D$. tamalis paracme by Sprovieri et al. (1994). Above the paracme, D. tamalis is again present with relatively high abundance for another short interval before abruptly decreasing at its LCO (Sprovieri et al., 1994). This distribution pattern allows easy and unambiguous identification of the top of this biozone. Unfortunately, at Hole 969E the available samples were not spaced to allow the clear identification of this event. In Hole 969E, the paracme interval is represented by only one sample. Also the short interval, above the paracme event, in which $D$. tamalis is present again with relatively high abundance, is also represented by only one sample. Consequently, the LCO and LO of D. tamalis are nearly coincident. The detailed quantitative distribution of $D$. tamalis at the top of its range was identified with accuracy at Site 964 (Sprovieri et al., Chap. 12 , this volume), for which closely spaced samples were analyzed.

\section{Discoaster triradiatus Increase}

Several studies report that in the uppermost part of the range of Discoaster brouweri, D. triradiatus strongly increases in abundance and the ratio between the two species indicates higher percentages values of $D$. triradiatus vs. D. brouweri. Backman and Shackleton (1983) proposed values consistently greater than $20 \%$ to recognize the interval of the increase of $D$. triradiatus, but Rio et al. (1990) proposed a threshold of $40 \%$ to recognize this event within the Mediterranean Basin. The relative abundance pattern of these species in several Mediterranean sequences shows a short increase in abundance of D. triradiatus, followed upward by a short interval with very low percent values, and then by an interval with consistent high percent values up to the extinction level of the two species. At Site 964 (Sprovieri et al., Chap. 12, this volume), above the first abundance peak, which correlates with oxygen isotopic Stage 85, the abundance of $D$. triradiatus fluctuates strongly, with values as high as $50 \%$. This peak abundance is intercalated by short intervals during which $D$. triradiatus strongly decreases below this value. At Hole 969E, a larger sample spacing was used and the abundance shift for $D$. triradiatus 


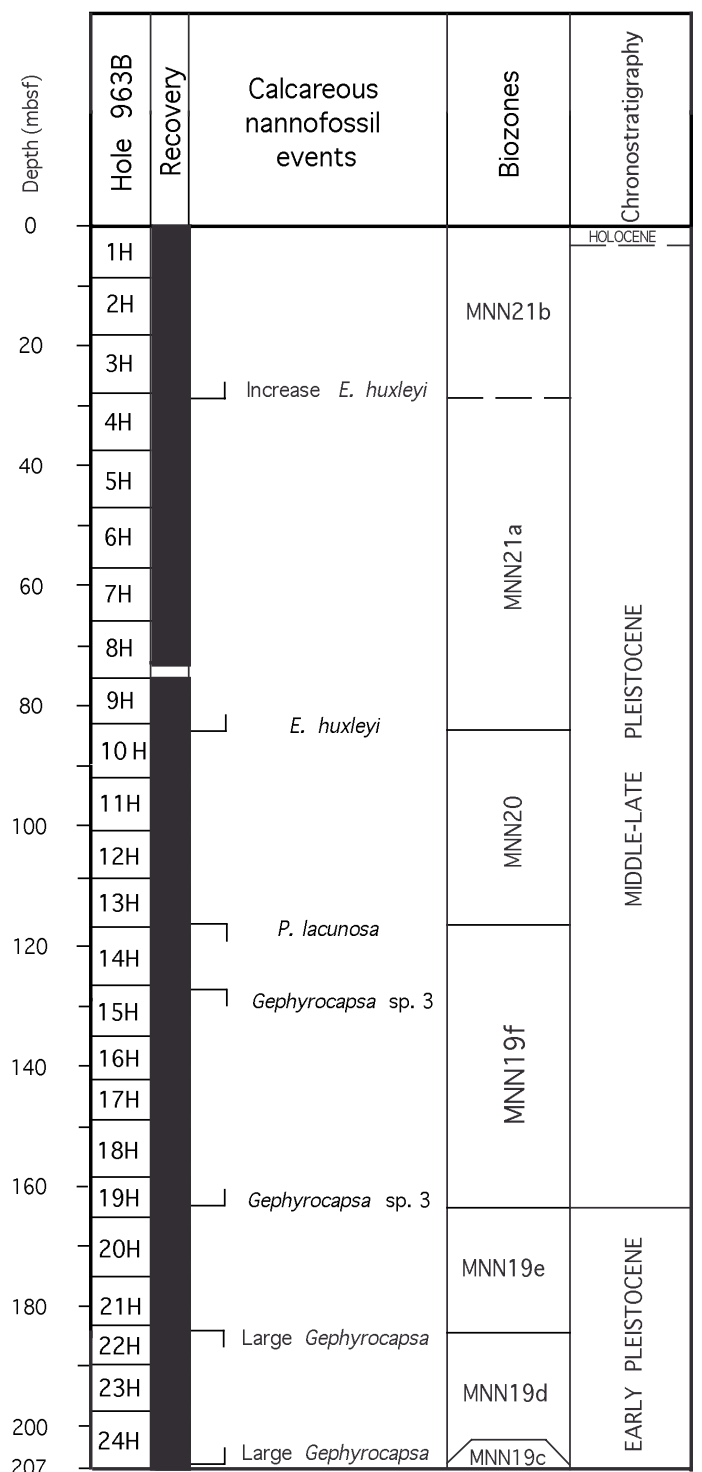

Figure 12. Composite of calcareous nannofossil biostratigraphic events recognized in Hole 963B.

was not recognized. The first abundance peak correlatable with oxygen isotopic Stage 85 is also not present, and the interval with high abundance of $D$. triradiatus is apparently continuous, with only one sample in which it is practically absent.

\section{Distribution Pattern of Gephyrocapsa sp. 3}

As a consequence of the high sediment-accumulation rate in Hole 963B, a detailed distribution pattern of Gephyrocapsa sp. 3 was observed within the MNN19f Zone. Gephyrocapsa sp. 3 shows wide relative abundance fluctuations, separated by short intervals in which it is absent. At Site 964 (Sprovieri et al., Chap. 12, this volume), where a detailed abundance pattern was also observed for this species, the second absence level above its FO correlates well with isotopic Stage 22. This correlation is in good agreement with the distribution of Gephyrocapsa sp. 3 in some Sicilian land sections (Di Stefano et al., 1991). At Cava Puleo-Ficarazzi (E. Di Stefano, unpubl. data; Vergnaud Grazzini et al., 1994), this taxon is not present in the interval identified as isotopic Stage 22.

The Gephyrocapsa sp. 3 LO occurs in the upper part of the MNN19f Zone, as already reported in other Mediterranean sequences by Rio et al. (1990) and Castradori (1993). Consequently, it can be
Table 2. Summary of the stratigraphic positions of calcareous nannofossil events at Hole 963B.

\begin{tabular}{|c|c|c|c|}
\hline Event & $\begin{array}{l}\text { Core, section, } \\
\text { interval }(\mathrm{cm})\end{array}$ & $\begin{array}{l}\text { Depth } \\
\text { (mbsf) }\end{array}$ & $\begin{array}{l}\text { Error limit } \\
\quad(\mathrm{cm})\end{array}$ \\
\hline & 160-963B- & & \\
\hline E. huxleyi increase & $4 \mathrm{H}-1,140-141$ & 29.4 & 80 \\
\hline E. huxleyi $\mathrm{FO}$ & $10 \mathrm{H}-2,71-72$ & 84.71 & 70 \\
\hline P. lacunosa LO & $13 \mathrm{H}-5,141-142$ & 116.31 & 70 \\
\hline Gephyrocapsa sp. 3 LO & $15 \mathrm{H}-1,71-72$ & 127.11 & 130 \\
\hline Gephyrocapsa sp. 3 FO & $19 \mathrm{H}-4,70-71$ & 163.6 & 70 \\
\hline Large Gephyrocapsa LO & $22 \mathrm{H}-1,70-71$ & 184.1 & 30 \\
\hline H. sellii $\mathrm{LO}$ & $22 \mathrm{H}-1,70-71$ & 184.1 & 30 \\
\hline Large Gephyrocapsa FO & $24 \mathrm{H}-6,140-141$ & 206.4 & 60 \\
\hline
\end{tabular}

Note: $\mathrm{FO}=$ first occurrence, $\mathrm{LO}=$ last occurrence.

considered a useful event for improving the stratigraphic resolution within this long zone. In the Eastern Mediterranean, Castradori (1993) recognized the LO of Gephyrocapsa sp. 3 between Sapropel S9 and the Brunhes/Matuyama boundary, at $\sim 584$ k.y. Castradori in Sanvoisin et al. (1993) correlated this event with climatic fluctuation (possibly correlatable with oxygen isotopic Stage 15). At Site 964, the LO of this taxon has been correlated with the middle part of isotopic Stage 15 (Sprovieri et al., Chap. 12, this volume).

\section{BIOCHRONOLOGY AND SEDIMENTATION RATE}

During the recent years, magnetobiostratigraphic results from Pliocene and lower Pleistocene Mediterranean sequences have been used to correlate calcareous plankton biostratigraphic events to the geomagnetic polarity time scale (Channell et al., 1988, 1990, 1992; Hilgen and Langereis, 1988; Zachariasse et al., 1989, 1990). Additionally, cyclostratigraphic results from both lithologic signals (Hilgen, 1991a, 1991b) and planktonic foraminiferal abundance fluctuations (Sprovieri, 1993) have enabled proposal of new, more refined ages for the chronostratigraphic and biostratigraphic boundaries. The ages used in this study for establishing sediment accumulation rates are reported in Table 3. Because Sprovieri (1993) did not report an age estimate for the $H$. sellii FO, the FO of Ceratolithus rugosus with its Mediterranean age evaluation (Berggren et al., 1995) was used for the Zanclean.

Sedimentation rates were calculated using as calibration points calcareous nannofossil events detected in each hole (Figs. 14, 15). The age data are plotted vs. depth. The line that connects the plotted points is the sedimentation rate curve. It was traced using depth value of the first or last sample where the marker species was found. An open square symbol is used to indicate the degree of uncertainty as to the position of the events within the holes.

\section{Hole 969E}

The sedimentation rate in Hole 969E (Fig. 14) shows some changes along the sequence. At the base of the Pliocene interval, $C$. rugosus FO and $D$. asymmetricus first common occurrence (FCO) events have been used as calibration points to interpolate the sedimentation curve. Extrapolation of this line in the MNN12 interval indicates that the base of the interval referred to this biozone cannot be older than 5.1 Ma. This is in good agreement with the biostratigraphic conclusions, which points out the absence of a distinct paracme interval of $R$. pseudoumbilicus. As a consequence, a hiatus is interpreted at the base of the MNN12 biozone. The hiatus is estimated to be $\sim 0.20$ m.y. in duration.

From the uppermost part of the Zanclean to the Piacenzian the sedimentation rates increase up to $2.9 \mathrm{~cm} / \mathrm{k}$.y. From this interval to the base of the Pleistocene, sediment accumulation is rather constant.

In the middle Pleistocene, between the Gephyrocapsa sp. 3 FO and the $P$. lacunosa LO, sediment accumulation appears to decrease, but this result may be affected by the wider spaced samples, which do 


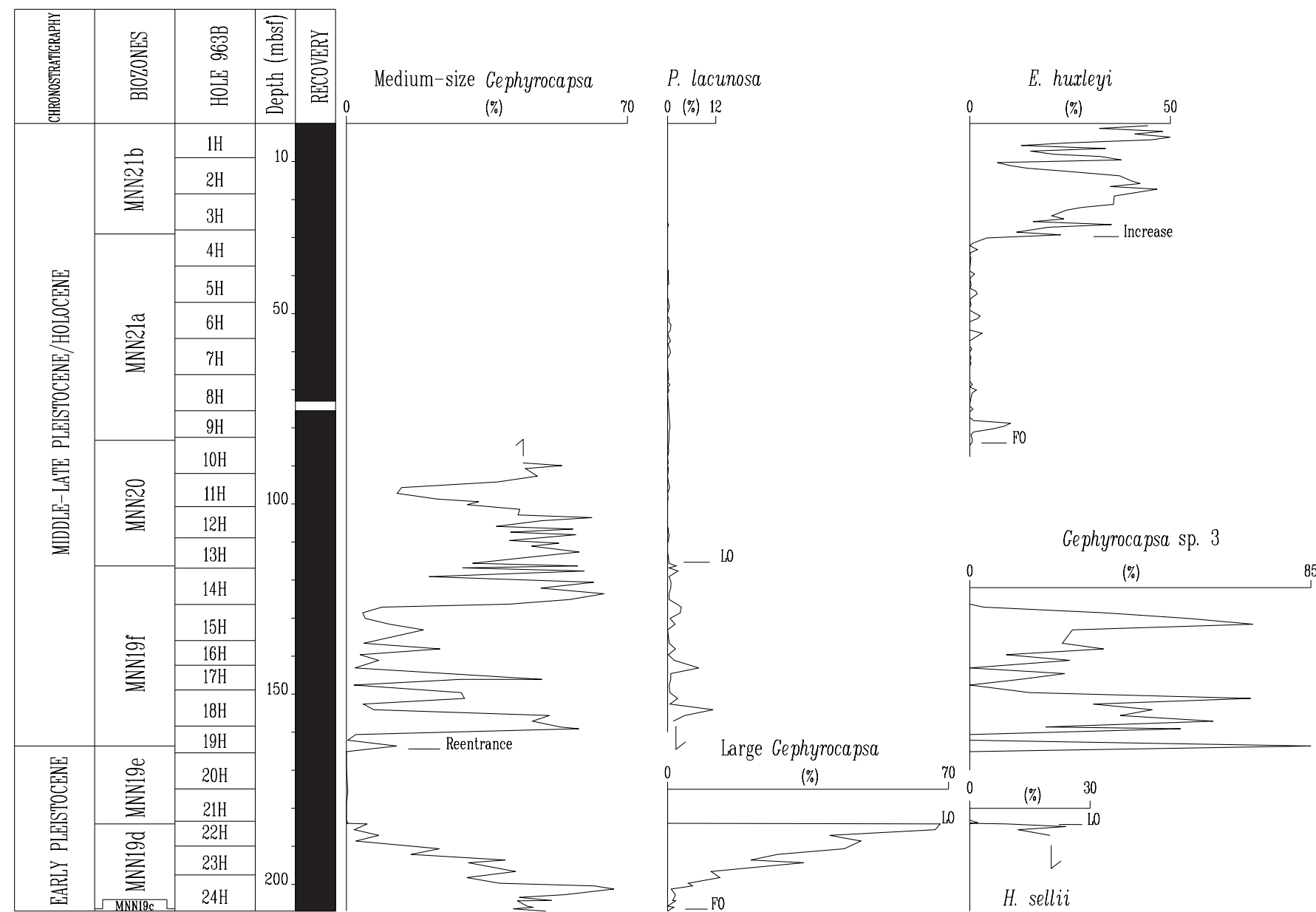

Figure 13. Abundance pattern of Pleistocene index forms in Hole 963B.

Table 3. Biochronology of Pliocene-Pleistocene calcareous nannofossils.

\begin{tabular}{lll}
\hline \multicolumn{1}{c}{ Event } & $\begin{array}{l}\text { Age } \\
\text { (Ma) }\end{array}$ & Reference \\
\hline E. huxleyi increase & 0.054 & 4 \\
E. huxleyi FO & 0.26 & 1 \\
P. lacunosa LO & 0.46 & 1 \\
Gephyrocapsa sp. 3 LO & 0.584 & 2 \\
Gephyrocapsa sp. 3 FO & 0.99 & 3 \\
Large Gephyrocapsa LO & 1.25 & 3 \\
Large Gephyrocapsa FO & 1.5 & 3 \\
C. macintyrei LO & 1.62 & 3 \\
Medium Gephyrocapsa FO & 1.75 & 3 \\
D. brouweri LO & 1.95 & 4 \\
D. triradiatus LO & 1.95 & 4 \\
D. pentaradiatus LO & 2.51 & 3 \\
D. tamalis LCO & 2.88 & 3 \\
D. pentaradiatus paracme top & 3.56 & 3 \\
Sphenolithus spp. LO & 3.73 & 3 \\
R. pseudoumbilicus LO & 3.85 & 3 \\
D. pentaradiatus paracme bottom & 3.9 & 3 \\
D. asymmetricus FCO & 4.11 & 3 \\
C. rugosus FO & 4.5 & 5 \\
R. pseudoumbilicus paracme top & 5.01 & 6 \\
\end{tabular}

Notes: In reference column, definitions are as follows: $1=$ Rio et al. (1990); 2 = Castradori (1993); 3 = Sprovieri (1993); 4 = Sprovieri et al. (Chap. 12, this volume); $5=$ Berggren et al. (1995); $6=$ Di Stefano et al. (1996). FO = first occurrence, $\mathrm{LO}=$ last occurrence. not allow accurate identification of biostratigraphic boundaries. Within the MNN21 Biozone the sedimentation rate increases again, with values above $2 \mathrm{~cm} / \mathrm{k} . \mathrm{y}$.

\section{Hole 963B}

At Hole 963B the sedimentation rate is higher than in Hole 969E, because of the different depositional setting (Fig. 15). According to the biostratigraphic data used as key points, a significant change in the sedimentation rate is present at $116.31 \mathrm{mbsf}$. From the base (207 $\mathrm{mbsf}$ ) to the $P$. lacunosa LO, the sedimentation rate ranges between $7.88 \mathrm{~cm} / \mathrm{k}$.y. and $9 \mathrm{~cm} / \mathrm{k}$.y. From this datum to the top, the sedimentation rate progressively increases up to $32.5 \mathrm{~cm} / \mathrm{k}$.y. This strong increase in the sedimentation rate is in good agreement with the presence of several ash layers reported in the upper $100 \mathrm{~m}$ (Shipboard Scientific Party, 1996) and is also supported by greater dilution of the autochthonous assemblages, presence of quartzose silt, foraminifer fragments, and increase of reworked taxa.

\section{CONCLUSION}

The distribution patterns of several biostratigraphically significant calcareous nannofossil markers within the Pliocene-Pleistocene record of Holes 969E and 963B have been studied using quantitative analyses. The data indicate that the floral assemblage evolution in time and in quantitative patterns compares well to similar studies reported from Western Mediterranean sequences, including ODP Site 
Figure 14. Age vs. depth diagram of the sediment accumulation rate Hole 969EThe line connects samples in which the marker species were found (first occurence or last occurrence datum). Open squares represent the error, considering the overlying or underlying sample in which the marker species was not found.

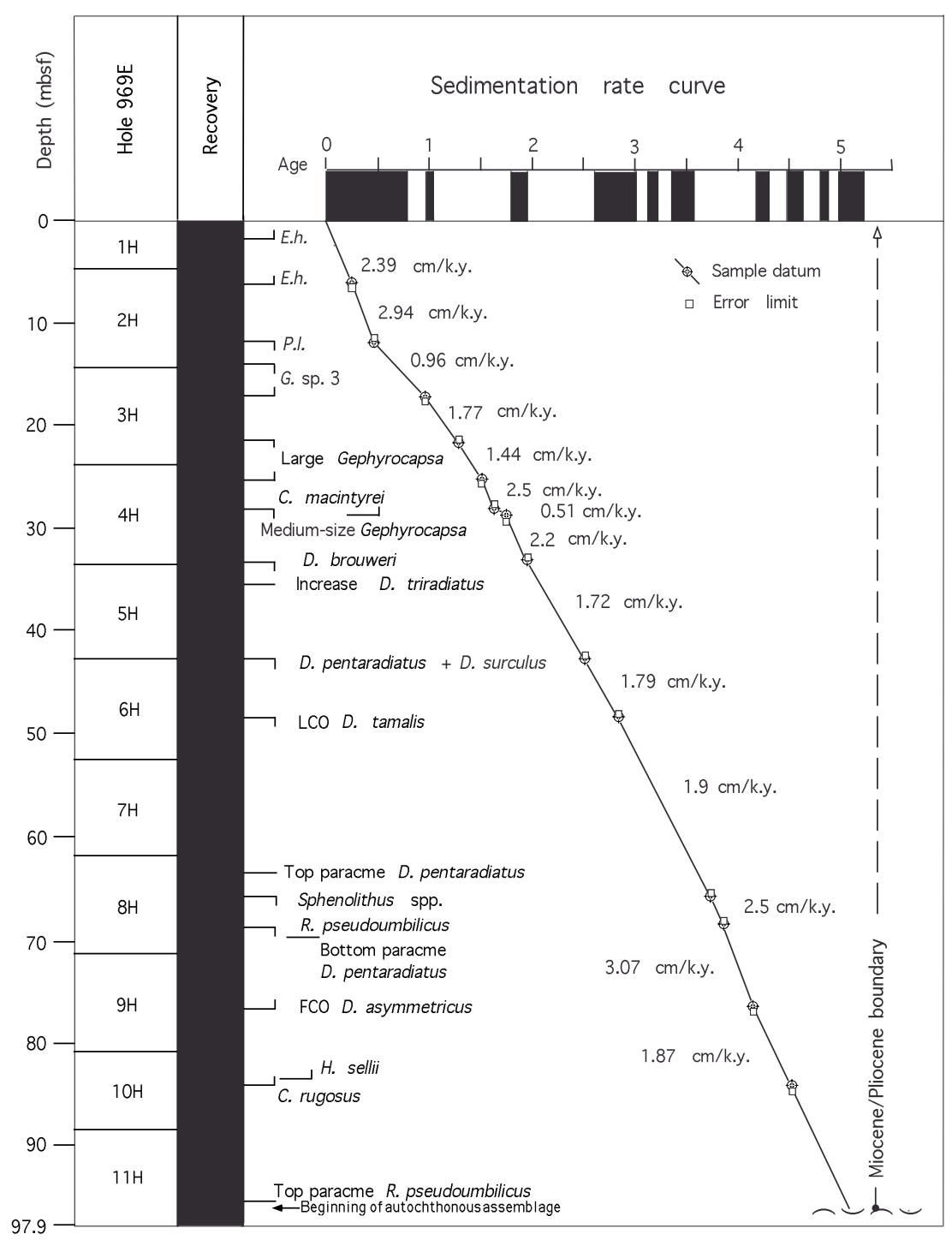

653. The traceability of the calcareous nannofossil events used as zonal markers and identified on the base of the same quantitative thresholds is reliable for the entire Mediterranean Pliocene-Pleistocene record.

Very detailed quantitative analyses in Mediterranean Pliocene sequences (Rio et al., 1990; Di Stefano et al. 1996; Sprovieri et al., 1994) pointed out the presence of the R. pseudoumbilicus and D. tamalis paracme, respectively in the lowermost part of MNN12 zone and in the uppermost part of MNN16a zone. These two short biostratigraphic intervals improve the biostratigraphic resolution of these long biozones and make possible a more accurate identification of the completeness of the sequence. In particular, since only the top of the $R$. pseudoumbilicus paracme interval was recognized at the base of the Hole 969E sequence, it can be concluded that a short segment at the base of the Pliocene is not present.

\section{ACKNOWLEDGMENTS}

This research was supported by C.N.R "Mediterraneo 2000" funds to M.B. Cita and by M.U.R.S.T. $60 \%$ grant to E. Di Stefano. Thanks are due to R. Sprovieri for the appreciated discussions and suggestions and to $\mathrm{S}$. Bonomo for his technical assistance. I thank D.
Castradori and T.S. Staerker for the scientific review of the manuscript and E. Kapitan-White who patiently reviewed the editorial part of the manuscript.

\section{REFERENCES}

Aguirre, E., and Pasini, G., 1985. The Pliocene-Pleistocene boundary. Episodes, 8:11-120.

Backman, J., and Shackleton, N.J., 1983. Quantitative biochronology of Pliocene and early Pleistocene calcareous nannofossils from the Atlantic, Indian and Pacific oceans. Mar. Micropaleontol., 8:141-170.

Bassett, M.G., 1985. Towards a "Common Language" in stratigraphy. Episodes, 8:87-92.

Benson, R.H., and Rakic-El Bied, K., 1996. The Bou Regreg Section, Morocco: proposed Global Boundary Stratotype Section and Point of the Pliocene. Notes Mem. Ser. Geol. Maroc, 383:51-150.

Berggren, W.A., 1984. Neogene plankton foraminiferal biostratigraphy and biogeography: Atlantic, Mediterranean and Indo-Pacific regions. In Tsuchi, R. (Ed.), Pacific Neogene Datum Planes: Tokyo (University of Tokyo Press), IGCP Proj. 114.

Berggren, W.A., Hilgen, F.J., Langereis, C.G., Kent, D.V., Obradovich, J.D., Raffi, I., Raymo, M.E., and Shackleton, N.J., 1995. Late Neogene chronology: new perspectives in high-resolution stratigraphy. Geol. Soc. Am. Bull., 107:1272-1287. 
Berggren, W.A., Kent, D.V., Flynn, J.J., and van Couvering, J.A., 1985. Cenozoic geochronology. Geol. Soc. Am. Bull., 96:1407-1418.

Bukry, D., 1973. Coccolith stratigraphy, Leg 13 Deep Sea Drilling Project. In Ryan, W.B.F., Hsü, K.J., et al., Init. Repts. DSDP, 13: Washington (U.S. Govt. Printing Office), 817-821.

Castradori, D., 1993. Calcareous nannofossil biostratigraphy and biochronology in eastern Mediterranean deep-sea cores. Riv. Ital. Paleontol. Stratigr., 99:107-126.

Channell, J.E.T., Di Stefano, E., and Sprovieri, R., 1992. Calcareous plankton biostratigraphy, magnetostratigraphy and paleoclimatic history of the Plio-Pleistocene Monte S. Nicola section (Southern Sicily). Boll. Soc. Paleontol. Ital., 31:351-382.

Channell, J.E.T., Rio, D., Sprovieri, R., and Glaçon, G., 1990. Biomagnetostratigraphic correlations from Leg 107 in the Tyrrhenian Sea. In Kastens, K.A., Mascle, J., et al., Proc. ODP, Sci. Results, 107: College Station, TX (Ocean Drilling Program), 669-682.

Channell, J.E.T., Rio, D., and Thunell, R.C., 1988. Miocene/Pliocene boundary magnetostratigraphy at Capo Spartivento, Calabria, Italy. Geology, 16:1096-1099.

Cita, M.B., 1975. The Miocene/Pliocene boundary: history and definition. In Saito, T., and Burckle, L.H., (Eds.), Late Neogene Epoch Boundaries. Spec. Publ. Micropaleontol., 1-30.

Cita, M.B., and Castradori, D., 1995. Rapporto sul workshop "Marine sections from the Gulf of Taranto (Southern Italy) useable as potential stratotypes for the GSSP of the Lower, Middle, and Upper Pleistocene" (29 settembre-4 ottobre 1994). Boll. Soc. Geol. Ital., 114:319-336.

Cita, M.B., and Gartner, S., 1973. Studi sul Pliocene e sugli strati al passaggio dal Miocene al Pliocene. IV. The stratotype Zanclean foraminiferal and nannofossil biostratigraphy. Riv. Ital. Paleontol. Stratigr., 79:503558

Cita, M.B., Rio, D., Hilgen, F., Castradori, D., Lourens, L., and Vergerio, P.P., 1996. Proposal of the Global Boundary Stratotype Section and Point (GSSP) of the Piacenzian Stage (middle Pliocene). Int. Comm. on Stratigr. Subcomm. on Neogene Stratigr.

Cita, M.B., Rio, D., and Sprovieri, R., in press. The Pliocene Series: chronology of the type Mediterranean record and standard chronostratigraphy. In Wrenn, J.H., and Suc, J.P. (Eds.), Paleoecology, Climate and Sequence Stratigraphy of the Pliocene. Am. Assoc. Strat. Palin., Spec. Vol.

Colalongo, M.L., and Sartoni, S., 1979. Schema biostratigrafico per il Pliocene ed il basso Pleistocene in Italia. Contr. Carta Neotett. Ital., 251:645-654.

Di Stefano, E., and Sprovieri, R., 1990. Calcareous plankton biostratigraphy of ODP Leg 107 Site 651 uppermost Pliocene-lowermost Pleistocene. Mem. Soc. Geol. Ital., 44:157-165.

Di Stefano, E., Sprovieri, R., and Caruso, A., 1993. High resolution biochronology in the Monte Narbone Formation of the Capo Rossello section and the Mediterranean first occurrence of Globorotalia truncatulinoides. Riv. Ital. Paleontol. Stratigr., 99:357-370.

Di Stefano, E., Sprovieri, R., and Scarantino, S., 1991. Biostratigrafia e paleoecologia della sezione intrapleistocenica di Casa Parrino (Foce del Belice, Sicilia Sud-Occidentale). Natural. Siciliano, 15:115-148.

, 1996. Chronology of biostratigraphic events at the base of the Pliocene. Paleopelagos, 6:401-414.

Driever, B.W.M., 1981. A quantitative study of Pliocene associations of Discoaster from the Mediterranean. Proc. K. Ned. Akad. Wet. 84:437-455. 1988. Calcareous nannofossil biostratigraphy and paleoenvironmental interpretation of the Mediterranean Pliocene. Utrecht Micropalaeontol. Bull., 36:1-245.

Ellis, C.H., 1979. Neogene Nannoplankton in Eastern Mediterranean. Ann. Geol. Pays Hell., 1:391-401.

Emeis, K.-C., Robertson, A.H.F., Richter, C., et al., 1996. Proc. ODP, Init. Repts., 160: College Station, TX (Ocean Drilling Program).

Glaçon, G., Rio, D., and Sprovieri, R., 1990. Calcareous plankton PliocenePleistocene biostratigraphy in the Tyrrhenian Sea (Western Mediterranean, Leg 107). In Kastens, K.A., Mascle, J., et al., Proc. ODP, Sci. Results, 107: College Station, TX (Ocean Drilling Program), 683-693.

Hilgen, F.J., 1991a. Astronomical calibration of Gauss to Matuyama sapropels in the Mediterranean and implication for the geomagnetic polarity time scale. Earth Planet. Sci. Lett., 104:226-244.

1991b. Extension of the astronomically calibrated (polarity) time scale to the Miocene/Pliocene boundary. Earth Planet. Sci. Lett., 104:211-225
Hilgen, F.J., and Langereis, C., 1993. A critical re-evaluation of the Miocene/ Pliocene boundary as defined in the Mediterranean. Earth Planet. Sci. Lett., 118:167-179.

Hilgen, F.J., and Langereis, C.G., 1988. The age of the Miocene-Pliocene boundary in the Capo Rossello area (Sicily). Earth Planet. Sci. Lett., 91:214-222.

Iaccarino, S., 1985. Mediterranean Miocene and Pliocene planktic foraminifera. In Bolli, H.M., Saunders, J.B., and Perch-Nielsen, K. (Eds.), Plankton Stratigraphy: Cambridge (Cambridge Univ. Press), 283-314.

Martini, E., 1971. Standard Tertiary and Quaternary calcareous nannoplankton zonation. In Farinacci, A. (Ed.), Proc. 2nd Int. Conf. Planktonic Microfossils Roma: Rome (Ed. Tecnosci.), 2:739-785.

Müller, C., 1978. Neogene calcareous nannofossils from the Mediterranean-Leg 42A of the Deep Sea Drilling Project. In Hsü, K.J., Montadert, L., et al., Init. Repts DSDP, 42 (Pt. 1): Washington (U.S. Govt. Printing Office), 727-751.

1990. Nannoplankton biostratigraphy and paleoenvironmental interpretations from the Tyrrhenian Sea, ODP Leg 107 (Western Mediterranean). In Kastens, K.A., Mascle, J., et al., Proc. ODP, Sci. Results, 107: College Station, TX (Ocean Drilling Program), 495-511.

Okada, H., and Bukry, D., 1980. Supplementary modification and introduction of code numbers to the low-latitude coccolith biostratigraphic zonation (Bukry, 1973; 1975). Mar. Micropaleontol., 5:321-325.

Raffi, I., Backman, J., Rio, D., and Shackleton, N.J., 1993. Plio-Pleistocene nannofossil biostratigraphy and calibration to oxygen isotopes stratigraphies from Deep Sea Drilling Project Site 607 and Ocean Drilling Program Site 677. Paleoceanography, 8:387-408.

Raffi, I., and Rio, D., 1979. Calcareous nannofossil biostratigraphy of DSDP Site 132-Leg 13 (Tyrrhenian Sea-Western Mediterranean). Riv. Ital. Paleontol. Stratigr., 85:127-172.

Rio, D., Raffi, I., and Villa, G., 1990. Pliocene-Pleistocene calcareous nannofossil distribution patterns in the Western Mediterranean. In Kastens, K.A., Mascle, J., et al., Proc. ODP, Sci. Results, 107: College Station, TX (Ocean Drilling Program), 513-533.

Rio, D., Sprovieri, R., and Di Stefano, E., 1994. The Gelasian stage: a proposal for a new chronostratigraphic unit of the Pliocene series. Riv. Ital. Paleontol. Stratigr., 100:103-124.

Rio, D., Sprovieri, R., and Raffi, I., 1984. Calcareous plankton biostratigraphy and biochronology of the Pliocene-lower Pleistocene succession of the Capo Rossello area, Sicily. Mar. Micropaleontol., 9:135-180.

Rio, D., Sprovieri, R., Raffi, I., and Valleri, G., 1988. Biostratigrafia e paleoecologia della sezione stratotipica del Piacenziano. Boll. Soc. Paleontol. Ital., 27:213-238.

Rio, D., Sprovieri, R., and Thunell, R., 1991. Pliocene-lower Pleistocene chronostratigraphy: a re-evaluation of Mediterranean type sections. Geol. Soc. Am. Bull., 103:1049-1058.

Sanvoisin, R., d'Onofrio, S., Lucchi, R., Violanti, D., and Castradori, D., 1993. 1 Ma paleoclimatic record from the Eastern MediterraneanMARFLUX project: first results of a micropaleontological and sedimentological investigation of a long piston core from the Calabrian Ridge. Il Quaternario, 6:169-188.

Schmidt, R.R., 1973. A calcareous nannoplankton zonation for upper Miocene-Pliocene deposits from the Southern Aegean area, with a comparison to Mediterranean stratotype localities. Proc. K. Ned. Akad. Wet., Ser. B: Paleontol., Geol., Phys., Chem., 76:287-310.

Shipboard Scientific Party, 1996. Site 963. In Emeis, K.-C., Robertson, A.H.F., Richter, C., et al., Proc. ODP, Init. Repts., 160: College Station, TX (Ocean Drilling Program), 55-84.

Spaak, P., 1983. Accuracy in correlation and ecological aspects of the planktonic foraminiferal zonation of the Mediterranean Pliocene. Utrecht Micropaleontol. Bull., 28:1-160.

Sprovieri, R., 1992. Mediterranean Pliocene biochronology: a high resolution record based on quantitative planktonic foraminifera distribution. Riv. Ital. Paleontol. Stratigr., 98:61-100.

1993. Pliocene-early Pleistocene astronomically forced planktonic foraminifera abundance fluctuations and chronology of Mediterranean calcareous plankton bio-events. Riv. Ital. Paleontol. Stratigr, 99:371-414.

Sprovieri, R., Di Stefano, E., Riggi, A., and Busalacchi, P., 1994. La sezione intra-pliocenica di Gibil-Gabel (Caltanissetta, Sicilia centrale): un esercizio di biostratigrafia ad alta risoluzione. Boll. Soc. Paleont. It., 33:289298. 
Thierstein, H.R., Geitzenauer, K., Molfino, B., and Shackleton, N.J., 1977. Global synchroneity of late Quaternary coccolith datum levels: validation by oxygen isotopes. Geology, 5:400-404.

Thunell, R.C., 1979. Mediterranean Neogene planktonic foraminiferal biostratigraphy: quantitative results from DSDP Sites 125, 132 and 372. Micropaleontology, 25:412-437.

Vergnaud-Grazzini, C., Capotondi, L., and Lourens, L., 1994. A refined Pliocene to early Pleistocene chronostratigraphic frame at ODP Hole 653A (West Mediterranean). Mar. Geol., 117:329-349.

Zachariasse, W.J., Gudjonsson, L., Hilgen, F.J., Langereis, C.G., Lourens L.J., Verahallen, P.J.J.M., and Zijderveld, J.D.A., 1990. Late Gauss to early Matuyama invasion of Neogloboquadrina atlantica in the Mediter- ranean and associated record of climatic change. Paleoceanography, $5: 239-252$.

Zachariasse, W.J., Zijderveld, J.D.A., Langereis, C.G, Hilgen, F.J., and Verahallen, P.J.J.M., 1989. Early late Pliocene Biochronology and surface water temperature variations in the Mediterranean. Mar. Micropaleontol., $14: 339-355$.

Date of initial receipt: 8 January 1997

Date of acceptance: 11 August 1997

Ms 160SR-009
Figure 15. Age vs. depth diagram of the sediment accumulation rate in Hole 963B. Conventions as in Figure 14.

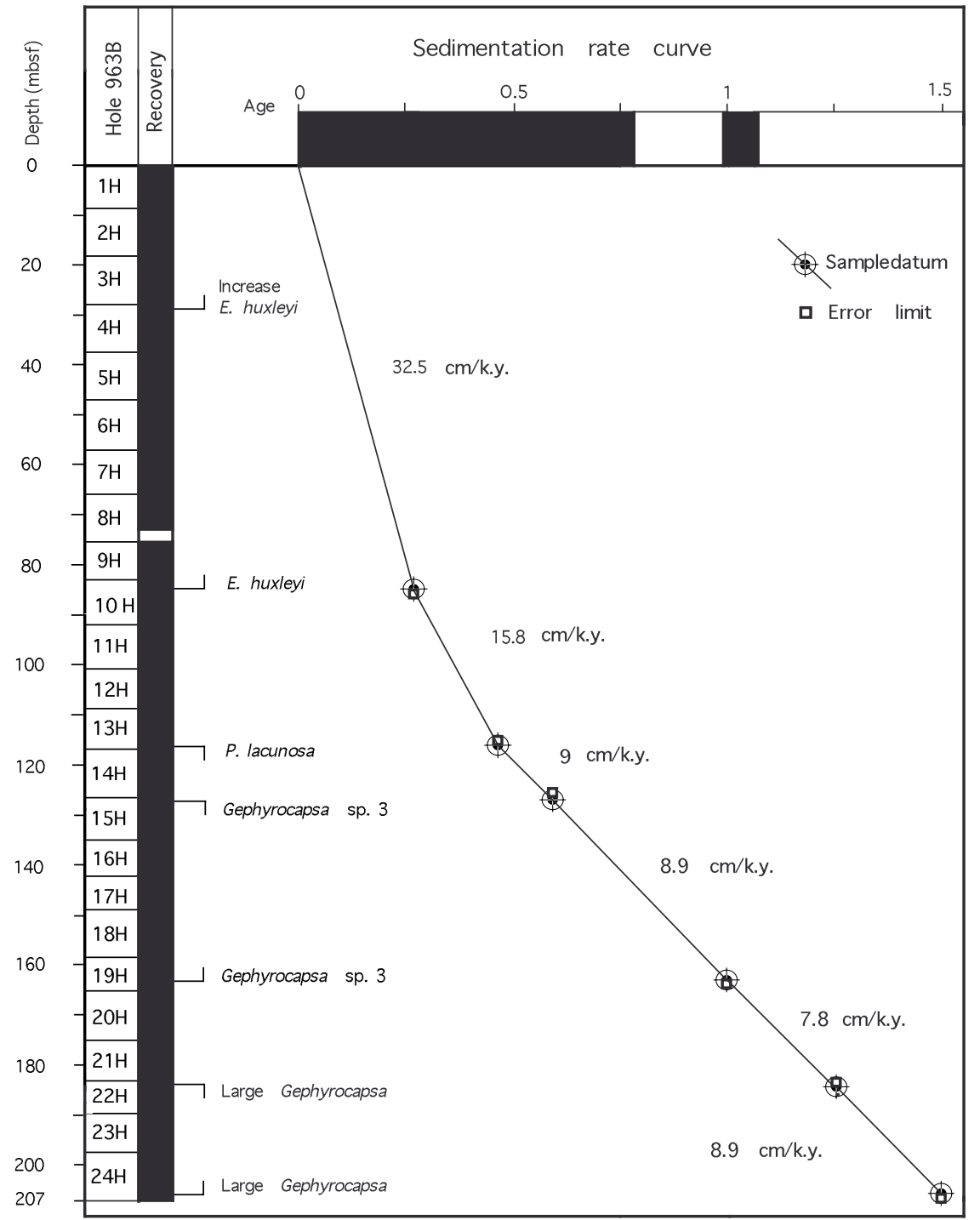

